\title{
NEW RECORDS OF MARINE FISHES FROM THE CORAL REEFS AND DEEP WATERS OF GULF OF MANNAR, INDIA
}

\author{
Vinay P. PADATE ${ }^{1}$, Chandrashekher U. RIVONKER ${ }^{1 *}$, A. Chandrashekar ANIL ${ }^{2}$, \\ Subhash S. SAWANT², and VENKAT Krishnamurthy ${ }^{2}$ \\ ${ }^{1}$ Department of Marine Sciences, Goa University, Taleigao Plateau, Goa, India \\ ${ }^{2}$ CSIR-National Institute of Oceanography, Dona Paula, Goa, India
}

Padate V.P., Rivonker C.U., Anil A.C., Sawant S.S., Venkat K. 2017. New records of marine fishes from the coral reefs and deep waters of Gulf of Mannar, India. Acta Ichthyol. Piscat. 47 (2): 145-161.

\begin{abstract}
Background. The coral reefs and deep water ecosystems of Gulf of Mannar support diverse assemblages of marine fishes vulnerable to indiscriminate mechanized fishing. However, lack of comprehensive information on the fish diversity of these ecosystems is aggravated by the habitat complexity of the fishing grounds, inadequate faunistic surveys and insufficient taxonomic expertise. In view of this, the present paper aims to document rare fishes and supplement the existing species inventory from this region.

Materials and methods. Sampling surveys included 23 hauls on-board commercial single-day otter trawlers operating bottom trawls at 15-100 m depths, and mid-water trawls at 100-153 m depths in the Gulf of Mannar. In addition, by-catch landings of commercial trawlers were surveyed at Tuticorin fishing harbour. Specimens were subjected to morphometric and meristic examination and deposited at the Central Marine Fisheries Research Institute, Kochi.

Results. The presently reported survey of rare fishes revealed one elasmobranch, Hypogaleus hyugaensis (Miyosi, 1939). In addition, 12 species of teleosts belonging to four orders, 10 families, and 11 genera were identified as Uropterygius micropterus (Bleeker, 1852); Dendrochirus bellus (Jordan et Hubbs, 1925); Snyderina guentheri (Boulenger, 1889); Acropoma japonicum Günther, 1859; Gymnocranius elongatus Senta, 1973; Pomacentrus similis Allen, 1991; Pristotis cyanostigma Rüppell, 1838; Leptojulis cyanopleura (Bleeker, 1853); Naso annulatus (Quoy et Gaimard, 1825); Naso thynnoides (Cuvier, 1829); Pseudalutarius nasicornis (Temminck et Schlegel, 1850); and Lagocephalus suezensis Clark et Gohar, 1953. The present paper provides descriptions of each species supplemented with meristic counts and morphometric measurements. An identification key to these species is provided.

Conclusion. Hypogaleus hyugaensis, U. micropterus, D. bellus, P. cyanostigma, N. thynnoides, P. nasicornis, and L. suezensis represent the first records in Indian waters. Additionally, G. elongatus, P. similis, and N. annulatus represent the first records off the Indian mainland, and S. guentheri, A. japonicum, and L. cyanopleura represent the first records off the East coast of India. Among these, D. bellus, S. guentheri, and P. cyanostigma represent the first records outside their known zoogeographical ranges. Patchy zoogeographical distribution and extension of known geographical ranges are attributed to recurrence of vicariance events in the geological past.
\end{abstract}

Keywords: rare fishes, bottom trawl, new records, taxonomy, morphometry

\section{INTRODUCTION}

The Gulf of Mannar with an area of $10500 \mathrm{~km}^{2}$ is situated off the southeast coast of India and comprises 21 small islands surrounded by fringing coral reefs (Venkataraman et al. 2004). The sub-tidal habitats comprise live coral cover, coral boulders with encrusting algal beds at 10-50 m depths (Prakash and Kumar 2016). Thomas (1970) described new sponges associated with deep water corals of the genus Pachyseris up to $180 \mathrm{~m}$ depth indicating the existence of deep water reefs in this region. This ecosystem reportedly supports $>900$ reef- associated finfish species, which are being gradually removed by large scale mechanized fishing (Yogesh Kumar et al. 2013). This region is also prone to tremendous anthropogenic pressure owing to large scale industrial and shipping activities, which are potentially hazardous to the fragile coral reefs and sea-grass habitats (Kathal 2005).

Therefore, in order to assess the diversity of demersal fishes in the Gulf of Mannar, trawling surveys onboard commercial trawlers were undertaken off the V.O. Chidambaranar Port, Tuticorin. These surveys revealed thirteen new records of rare fishes in the Indian 
waters, and supplement the existing information pertaining to the finfish diversity in this region.

\section{MATERIALS AND METHODS}

The area of the presently reported study encompasses the trawling grounds in the Gulf of Mannar, located off the south-eastern coast of India (Fig. 1) from 15 through $153 \mathrm{~m}$ depth. The bathymetry of the study area (between latitudes $8^{\circ} 27^{\prime} 54^{\prime \prime} \mathrm{N}$ and $8^{\circ} 52^{\prime} 43^{\prime \prime} \mathrm{N}$ and longitudes $78^{\circ} 12^{\prime} 33^{\prime \prime} \mathrm{E}$ and $78^{\circ} 32^{\prime} 38^{\prime \prime} \mathrm{E}$ ) is characterized by gentle gradient from the shoreline to $20 \mathrm{~m}$ depth, followed by slightly steep gradient between $20 \mathrm{~m}$ and $50 \mathrm{~m}$ depth contours, and very steep gradient between $50 \mathrm{~m}$ and 500 $\mathrm{m}$ depth contours (Anonymous 2010).

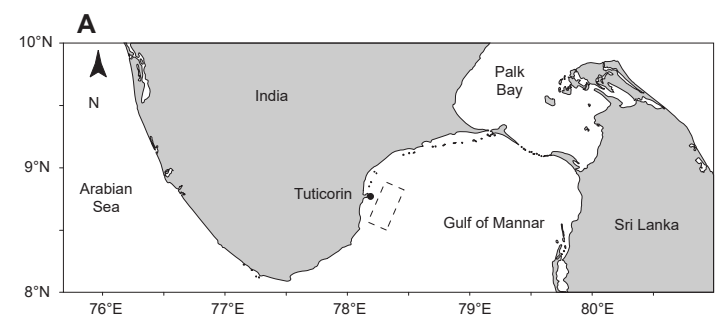

B

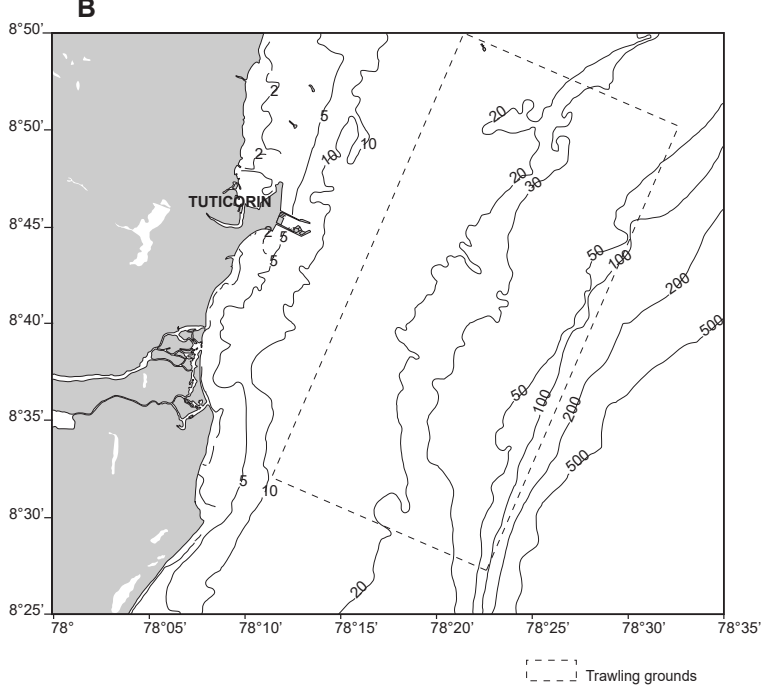

Fig. 1. Geographical location of study area (A), Detailed map of the study area indicating the sampling site (B)

Sampling surveys were carried on-board commercial single-day otter trawlers operating bottom trawls at 15$100 \mathrm{~m}$ depths, and mid-water trawls at $100-153 \mathrm{~m}$ depths in the Gulf of Mannar during July 2012 to March 2013 with a total effort of 35 man hours. Altogether, 23 bottom trawl hauls were examined. Rare fishes hauled up by trawl nets were collected, photographed, temporarily preserved on ice, and taken to the laboratory for detailed examination. Additionally, rare fishes were also collected from by-catch of commercial trawlers at Tuticorin fisheries harbour.

At the laboratory, taxonomic identification was carried out following FAO Species Identification Sheets (Carpenter and Allen 1989, Compagno and Niem 1998, Böhlke et al. 1999, Poss 1999, Allen 2001, Hutchins 2001, Matsuura 2001, Randall 2001a, Westneat 2001). Detailed morphometric and meristic studies of each species were carried out following the specifications provided by published literature relevant to each taxon. Morphometric measurements of Hypogaleus hyugaensis (Miyosi, 1939) and Uropterygius micropterus (Bleeker, 1852) are expressed as percentages of Total Length, whereas those of the other eleven species are expressed as percentages of Standard Length.

Reference voucher samples were deposited in the Marine Biodiversity Museum of Central Marine Fisheries Research Institute, Kochi (a designated national repository), and accession numbers to specimens are provided in the Results section.

The following abbreviations are used in the text: $\mathrm{A}=$ anal fin, $\mathrm{BD}=$ body depth, $\mathrm{BW}=$ body width, $\mathrm{C}=$ caudal fin, $\mathrm{CPD}=$ caudal peduncle depth, $\mathrm{CPL}=$ caudal peduncle length, $\mathrm{CPW}=$ caudal peduncle width, $\mathrm{D}=$ dorsal fin, $\mathrm{D}_{1}=$ first dorsal fin, $\mathrm{D}_{2}=$ second dorsal fin, $\mathrm{ED}=$ eye diameter, $\mathrm{GR}$, number of gill rakers, $\mathrm{HH}=$ head height, $\mathrm{HL}=$ head length, HW= head width, INS = inter-nasal space, IOW = inter-orbital width, $\mathrm{LJL}=$ lower jaw length, $\mathrm{LS}=$ lateral line scales, $\mathrm{ML}=$ mouth length, $\mathrm{P}=$ pectoral fin, $\mathrm{PAL}=$ pre-anal length, $\mathrm{PDL}=$ pre-dorsal length, $\mathrm{POL}=$ pre-oral length, $\mathrm{POS}=$ pre-orbital snout length, $\mathrm{PPL}=$ pre-pectoral length, $\mathrm{PVL}=$ pre-pelvic fin, $\mathrm{SL}=$ standard length, $\mathrm{SnL}=$ snout length, $\mathrm{TL}=$ total length, UJL = upper jaw length, $\mathrm{V}=$ pelvic fin.

The presently reported study was carried out on board commercial trawlers in accordance with the Indian national regulations and did not require any special permit.

\section{RESULTS}

The presently reported survey of rare fishes for the Gulf of Mannar revealed one elasmobranch, Hypogaleus hyugaensis (Miyosi, 1939). In addition, 12 species of teleosts belonging to four orders, 10 families, and 11 genera were identified as Uropterygius micropterus (Bleeker, 1852); Dendrochirus bellus (Jordan et Hubbs, 1925); Snyderina guentheri (Boulenger, 1889); Acropoma japonicum Günther, 1859; Gymnocranius elongatus Senta, 1973; Pomacentrus similis Allen, 1991; Pristotis cyanostigma Rüppell, 1838; Leptojulis cyanopleura (Bleeker, 1853); Naso annulatus (Quoy et Gaimard, 1825); Naso thynnoides (Cuvier, 1829); Pseudalutarius nasicornis (Temminck et Schlegel, 1850); and Lagocephalus suezensis Clark et Gohar, 1953.

\section{Order Carcharhiniformes Compagno, 1977 Family Triakidae Gray, 1851 Genus Hypogaleus Smith, 1957}

Hypogaleus Smith, 1957: 589 (type species: Galeorhinus (Hypogaleus) zanzibarensis Smith, 1957 by original designation; monotypic).

Remarks. It is a monotypic genus distributed off South Africa, Tanzania, Kenya, Arabian Gulf, Taiwan, Japan, and south-western Australia (Compagno and Niem 1998). The presently reported observation constitutes the first record from Indian waters. 


\section{Hypogaleus hyugaensis (Miyosi, 1939)}

\section{Fig. 2A}

Eugaleus hyugaensis Miyosi, 1939: 91, fig. 1 (type locality: off Hyuga Nada, east coast of Miyazaki Prefecture, Japan, 40-60 m).

Galeorhinus (Hypogaleus) zanzibarensis Smith, 1957: 589, fig. 2, pl. 19 (type locality: Zanzibar, Tanzania).

Hypogaleus zanzibarensis Smith, 1957: Smith and Heemstra 1986: 79.

Hypogaleus hyugaensis (Miyosi, 1939): Smith and Heemstra 1986: 79, fig. 9.22.

Material. GA.1.8.8.18, $(1, \quad 330.00 \quad \mathrm{~mm} \quad \mathrm{TL})$, $8^{\circ} 27^{\prime} 54^{\prime \prime} \mathrm{N}, 78^{\circ} 22^{\prime} 45^{\prime \prime} \mathrm{E}-8^{\circ} 34^{\prime} 10^{\prime \prime} \mathrm{N}, 78^{\circ} 24^{\prime} 55^{\prime \prime} \mathrm{E}$, Gulf of Mannar, 103 m, 11 October 2012.

Diagnosis. Body slender, brownish grey dorsally; mouth angular. Last gill pair posterior to $\mathrm{P}$ origin. $\mathrm{D}_{1}$ base 0.7 times in $\mathrm{C}$ length, its base anterior to V; $\mathrm{D}_{1} 2.0$ times larger than $\mathrm{D}_{2}, \mathrm{D}_{2}$ origin anterior to $\mathrm{A} ; \mathrm{D}_{2}$ larger than $\mathrm{A}$. Caudal peduncle lacking pre-caudal pits. Lower caudal lobe strong; upper edge smooth; $\mathrm{C}$ terminal lobe one-thirds as long as total $\mathrm{C}$ dorsal surface.

Description. Body slender, brownish grey on back and sides, ventral surface drab grey. Head long (PPL 23.12\% of TL), snout depressed, moderately long (POL $7.10 \%$ of TL, POS $6.66 \%$ of TL), anterior nasal flaps rudimentary, INS wide $(3.87 \%$ of TL). Mouth moderately long (ML $3.42 \%$ of TL), profile angular, upper labial furrow moderately long (1.71\% of TL). Eye large (ED 3.86\% of TL), IOW $4.49 \%$ of TL. Last gill pair posterior to P origin. $\mathrm{P}$ moderately large, anterior and posterior fin margins $14.41 \%$ and $6.71 \%$ of TL, respectively. Two unequal dorsal fins with dark apices. $\mathrm{D}_{1}$ two times larger than $\mathrm{D}_{2}$, inserted behind $\mathrm{P}$ origin, base anterior to $\mathrm{V}$ fin, 0.7 times in $C$ length. $\mathrm{D}_{2}$ origin anterior to $\mathrm{A} ; \mathrm{D}_{2}$ larger than $\mathrm{A}$. Interdorsal space $24.43 \%$ of TL. V anterior margin short $(4.60 \%$ of TL). A moderately large, (height $4.78 \%$ of TL). Analcaudal space long ( $9.71 \%$ of TL), lacks pre-caudal pits. C asymmetrical, lower lobe strong; upper edge smooth; $\mathrm{C}$ terminal lobe one-thirds as long as total $\mathrm{C}$ dorsal surface.

Distribution. Hypogaleus hyugaensis is known to inhabit the bottom waters of the continental shelf up to $230 \mathrm{~m}$ depth (Compagno and Niem 1998). Previously known from Japan, South Africa, Tanzania, Kenya, Taiwan, Arabian Gulf, and south-western Australia (Compagno and Niem 1998). This specimen represents the first record in the Indian waters.

Remarks. Three triakid species namely Iago omanensis (Norman, 1939); Mustelus mangalorensis Cubelio, Remya et Kurup, 2011; and Mustelus mosis Hemprich et Ehrenberg, 1899 are hitherto known from the Indian waters (Fischer and Bianchi 1984, Cubelio et al. 2011).

The identification of the presently reported specimen following the dichotomous key to species of the family Triakidae (see Fischer and Bianchi 1984) revealed that in the first step, this specimen differed from Scylliogaleus quecketti Boulenger, 1902 in having rudimentary nasal flaps widely spaced from each other (nasal flaps large and meet each other in the latter species). Moreover, it lacks nasoral grooves (present in the latter species).
According to the second step, this specimen possesses rudimentary anterior nasal flap, a prominent ventral caudal lobe, its $\mathrm{D}_{2}$ is half the size of $\mathrm{D}_{1}$. On the other hand, sharks of the genera Iago and Mustelus possess short anterior nasal flap, short ventral caudal lobe and $\mathrm{D}_{2}$ almost as large as $\mathrm{D}_{1}$. In the third step, this specimen keys out as Hypogaleus hyugaensis owing to an angular mouth, $\mathrm{D}_{2}$ larger than $\mathrm{A}$, and terminal lobe of caudal fin one-thirds in length of total caudal fin dorsal margin length. The other species in the third step, Galeorhinus galeus (Linnaeus, 1758) possesses an arcuate mouth, equally large $\mathrm{D}_{2}$ and $\mathrm{A}$, and a comparatively longer terminal lobe of caudal fin.

\section{Order Anguilliformes Berg, 1940 Family Muraenidae Rafinesque, 1810 Subfamily Uropterygiinae Fowler, 1925 Genus Uropterygius Rüppell, 1838} Uropterygius Rüppell, 1838: 83 (type species: Uropterygius concolor Rüppell, 1838, by monotypy).

Remarks. Uropterygius is distinguished from closely related genera in having short $\mathrm{D}$ and $\mathrm{A}$ fins restricted to caudal tip, mostly needle-like pointed teeth, presence of two hypobranchials, and absence of lateral line pores near posterior nostril (McCosker and Smith 1997). This genus comprises 20 valid species, out of which 16 are distributed in the Indo-western Pacific region, two in eastern Pacific region, and one each in eastern Atlantic and western Atlantic regions (Smith 2012). Among these, three species namely Uropterygius concolor; Uropterygius macrocephalus (Bleeker, 1864); and Uropterygius marmoratus (Lacepède, 1803) are known from the Indian waters (Rao et al. 2000).

\section{Uropterygius micropterus (Bleeker, 1852)}

Fig. 2B

Muraena micropterus Bleeker, 1852: 298 (type locality: Wahai, northern Ceram, Indonesia).

Uropterygius micropterus (Bleeker, 1852): Smith and Heemstra 1986: 175, fig. 41.31. Böhlke and McCosker 2001: 76 (key). Loh et al. 2008: 140, fig. 1G.

Material. GB.4.9.12.10, $(1,165.00 \mathrm{~mm}$ TL), by-catch landed at Tuticorin fisheries jetty, 10 July 2012.

Diagnosis. Body eel-like, slender, pale grey coloured, overlaid laterally and dorsally with a reticulation of fine, brown, worm-like lines. Body (head and trunk) slightly more than 2.0 times, tail slightly less than 2.0 times in total length. Head pores 13 (one branchial, two supraorbital, four infra-orbital, six mandibular). Posterior nostril not contiguous with supra-orbital pore. Teeth pointed, biserial. Single lateral-line pore above and before gill opening. Dorsal and anal fins restricted to tail tip.

Description. Body eel-like, slender (BD 3.72\% of TL, BD at gill opening $2.02 \%$ of TL, BD at anus $2.74 \%$ of TL, BW $2.46 \%$ of TL), pale to grey coloured, overlaid laterally and dorsally with a reticulation of fine, brown, worm-like lines. Anus positioned near mid-length, body (snout to anus distance) $47.43 \%$ of $\mathrm{TL}$, tail (anus to 
posterior caudal tip distance) $52.57 \%$ of TL. Head short (HL 12.79\% of TL). Head pores 13 (one branchial, two supra-orbital, four infra-orbital, six mandibular). Snout extremely short (SnL $1.59 \%$ of TL), snout tip to mouth corner $4.34 \%$ of TL. Mouth terminal, small (UJL 3.55\% of TL, LJL $4.32 \%$ of TL). Jaw teeth pointed, biserial, inner series long caniniform; vomerine teeth short caniniform. Posterior nostril located over front of eye, not contiguous with supra-orbital pore. Eye small (ED $0.67 \%$ of TL), IOW $0.92 \%$ of TL, eye to mouth corner distance $1.30 \%$ of TL. Single lateral-line pore above and before gill opening. Gill opening small (1.18\% of TL). D and A restricted to tail tip, embedded in skin. No trace of fin on mid-ventral surface just behind anus. C extremely short (longest middle ray $0.15 \%$ of TL).

Distribution. Previously known from the east coast of Africa to Japan, Australia, and the central Pacific regions (Loh et al. 2008). This specimen represents the first record in the Indian waters.

Remarks. The identification of the presently described specimen following the dichotomous key to subfamilies of family Muraenidae (see Böhlke et al. 1999) revealed that this specimen keyed out to subfamily Uropterygiinae owing to the restriction of the dorsal and anal fins to caudal tip. Subsequent identification following the key to species of subfamily Uropterygiinae revealed that in the first step, the specimen differed from Channomuraena vittata (Richardson, 1845) in having subequal jaws, long snout, and eye above middle of jaws. In the second step, this specimen differed from the genus Anarchias in lacking pore abutting posterior nostril. In the third step, it differed from the genus Scuticaria in having subequal head-trunk and tail due to middle position of anus, a character shared by all Uropterygius species. In the fourth step, it differed from Uropterygius fasciolatus (Regan, 1909); Uropterygius kamar McCosker et Randall, 1977; Uropterygius xanthopterus Bleeker, 1859; in having one pore anterior to gill opening. In the fifth step, this specimen differed from Uropterygius nagoensis Hatooka, 1984 in having one pore anterior to gill opening (the latter species may or may not have pore). In the sixth step, it differed from Uropterygius concolor Rüppell, 1838 and Uropterygius inornatus Gosline, 1958 (plain colour) in having markings on body. The subsequent three steps distinguished this specimen from Uropterygius polyspilus (Regan, 1909); U. marmoratus; and Uropterygius fuscoguttatus Schultz, 1953 (all three with different spotted patterns) in having vermiculate markings on body. In the tenth step, the specimen differed from Uropterygius supraforatus (Regan, 1909) in having biserial jaw teeth and vermiculate markings. In the eleventh step, the specimen keyed out as U. micropterus owing to brown vermiculate pattern, posterior nostril above front of eye, and $\mathrm{SnL}: \mathrm{ED}$ ratio of $2: 1$. The other two species in this step, $U$. macrocephalus possesses posterior nostril placed above the middle or posterior part of the eye, and $\mathrm{SnL}:$ ED ratio greater than $2: 1$.
Order Scorpaeniformes Greenwood, Rosen, Weitzman et Myers, 1966

Family Scorpaenidae Risso, 1826

Subfamily Pteroinae Kaup, 1873

Genus Dendrochirus Swainson, 1839

Dendrochirus Swainson, 1839: 180. (type species: Pterois zebra Cuvier, 1829, by subsequent designation).

Remarks. Dendrochirus is distinguished from closely related genera in having elongated dorsal fin with membrane deeply incised between spines, $\mathrm{P}$ with branched upper rays, fin membrane between these slightly incised, A with III spines and 5 soft rays (Poss 1999). This genus comprises six valid species, all of which are distributed in the Indo-Pacific regions (Poss 1999, Matsunuma and Motomura 2013). Among these, two species namely Dendrochirus brachypterus (Cuvier, 1829) and Dendrochirus zebra (Cuvier, 1829) are known from the Indian waters (Rao et al. 2000).

\section{Dendrochirus bellus (Jordan et Hubbs, 1925)} Fig. 2C

Brachirus bellus Jordan et Hubbs, 1925: 274, pl. X, fig. 3 (type locality: Misaki, Japan).

Dendrochirus bellus (Jordan et Hubbs, 1925): Poss 1999: 2312. Matsunuma and Motomura 2013: 1.

Materials. GB.38.24.11.10, (1, $72.86 \mathrm{~mm} \mathrm{SL})$, by-catch landed at Tuticorin fisheries jetty, 11 October 2012, (2, $65.99 \mathrm{~mm}$ SL and $52.46 \mathrm{~mm} \mathrm{SL})$, $8^{\circ} 47^{\prime} 49^{\prime \prime} \mathrm{N}, 78^{\circ} 23^{\prime} 07^{\prime \prime} \mathrm{E}-8^{\circ} 45^{\prime} 47^{\prime \prime} \mathrm{N}, 78^{\circ} 17^{\prime} 15^{\prime \prime} \mathrm{E}$, Gulf of Mannar, 16 m, 13 March 2013.

Diagnosis. Dorsal fin spines 13, dorsal fin rays 10; anal fin spines 3 , anal fin rays 5 , pectoral fin rays 17 , pelvic fin spine 1, pelvic fin rays 5. Total GR 20. Vertical scale rows about 36 . SnL $5.65 \%-8.45 \%$ of SL; HL $26.72 \%-41.31 \%$ of SL; BD $38.77 \%-40.85 \%$ of SL. Body with broad red vertical bars on a pale background; P bright red with six broad black bands, lower $P$ rays with alternating rows of light yellow and black spots.

Description. Dorsal fin spines 13, dorsal fin rays 10; anal fin spines 3, anal fin rays 5; pectoral fin rays 17; pelvic fin spine 1 , pelvic fin rays 5 . Total GR 20. Body deep (BD $38.77 \%-40.85 \%$ of SL), moderately slender (BW $22.00 \%-25.70 \%$ of SL), light reddish coloured with six broad, slightly darker bands. Head long (HL 26.72\%$41.31 \%$ of SL), robust (HW $22.49 \%-27.06 \%$ of SL), with short snout ( $\mathrm{SnL} 5.65 \%-8.45 \%$ of SL). Mouth large (UJL $16.81 \%-20.52 \%$ of SL, maxillary depth $5.07 \%-8.26 \%$ of SL), gape slightly oblique. Jaw teeth slender, conical, vomerine tooth patch V-shaped. Anterior nostril with short tentacle, another on ventral margin of lacrimal spine. Eyes large (ED 12.07\%-14.18 \% of SL); IOW narrow $(5.26 \%-6.75 \%$ of SL), with two longitudinal ridges. Nasal spine two-tipped; pre-ocular spine with four tips; supra-ocular spine with three points; post-ocular spine with nine tips; tympanic spine with two tips; coronal spine with three tips; parietal spine with wide base and one tip; nuchal spine with one tip; sphenotic spine with nine tips; pterotic spine with ten tips; lower post-temporal with one tip; supra-cleithral base serrated, one low spine 
at posterior edge; pre-opercular spines 3, uppermost spine largest and marked with distinct black blotch; sub-orbital ridge serrated in two distinct groups; lateral lacrimal ridge with 2 spines; posterior lacrimal spine directed posterolaterally. Scales large ctenoid, arranged in 36 vertical scale rows. Lateral line complete, sloping downwards; scales above lateral line 5. D origin above operculum (PDL 20.93\%-27.64\% of SL). D long (longest D spine $26.52 \%-29.55 \%$ of SL), membranes between spines deeply incised, (longest D ray $24.70 \%-26.69 \%$ of SL). $\mathrm{P}$ long (longest $\mathrm{P}$ ray $46.98 \%-49.41 \%$ of SL), reaching posterior end of A fin. P upper rays bright red with six broad black bands, lower rays bright red with alternating rows of light yellow and black spots. $\mathrm{V}$ origin slightly anterior to pectoral insertion (PVL 32.90\%-35.27\% of SL). V long (V spine $16.67 \%-20.59 \%$ of SL, longest V ray (30.31\%-32.94\% of SL), reaching beyond A origin. A origin under 12th dorsal spine (PAL 61.83\%-69.96\% of SL). A short (longest A spine $13.64 \%-20.97 \%$ of SL; longest A ray $27.28 \%-28.82 \%$ of SL). Caudal peduncle short (CPL 9.68\%-12.73\% of SL), deep (CPD $10.66 \%-12.35 \%$ of SL). C long $(28.79 \%-31.57 \%$ of SL). D, A, V, and C bright red with alternating rows of small-sized light yellow and black spots.

Distribution. Previously known from New Caledonia, Taiwan (Poss 1999) and Japan (Matsunuma and Motomura 2013). These specimens represent the first record in the Indian waters, and the first outside the known geographical range.

Remarks. The identification of the presently described specimens following the dichotomous key to species of Family Scorpaenidae (Poss 1999) revealed that these specimens with skin at gill openings connected to each other, immobile lacrimal bone, single spine at end of weak opercular ridge, elongated D fin with deeply incised membranes between spines and an elongated pectoral fin keyed out as Subfamily Pteroinae. Subsequently, these specimens differed from the genus Pterois in having branched pectoral fin rays; from Brachypterois in having $\mathrm{D}$ spines longer than 0.5 times $\mathrm{BD}$; from Parapterois in having A with III spines and 5 soft rays; and from Ebosia in having 3 pre-opercular spines and lacking bony crest above orbit. Further, within the genus Dendrochirus, they differed from Dendrochirus biocellatus (Fowler, 1938 ) in having $17 \mathrm{P}$ rays and lack of ocelli on D soft portion. Subsequently, it keyed out as $D$. bellus due to 36 vertical scale rows on body, short snout ( $\mathrm{SnL}<8 \%$ of $\mathrm{SL}$ ) and body colouration. The other two species in the step, namely, D. brachypterus and D. zebra possess more than 45 vertical scale rows on body, comparatively longer snout (SnL 11\%-15\% of SL) and darker colouration.

Further comparison of the presently described specimens with remaining two congeners not included in the key, Dendrochirus barberi (Steindachner, 1900) and Dendrochirus tuamotuensis Motsunuma et Motomura, 2013 (see Matsunuma and Motomura 2013) revealed marked differences in the number of $\mathrm{D}$ rays (10 vs. 9 each in the latter two species) and $\mathrm{P}$ rays (17 vs. 18 and 19 , respectively in the latter two species). In addition, these two species possess comparatively narrow head (HW $13.8 \%-17.2 \%$ of SL and $12.9 \%$ of SL, respectively), longer snout ( $\mathrm{SnL} 9.9 \%-13.3 \%$ of SL and $11.1 \%$ of SL, respectively), and longer $\mathrm{C}$ fin $(32.3 \%-43.9 \%$ of SL and $37.6 \%$ of SL, respectively).

\section{Family Tetrarogidae Smith, 1949 Genus Snyderina Jordan et Starks, 1901}

Snyderina Jordan et Starks, 1901: 381 (type species: Snyderina yamanokami Jordan et Starks, 1901, by monotypy).

Remarks. Snyderina is distinguished from closely related genera in having deep body (BD 34\% of SL), cycloid body scales, dorsal fin originating anterior to posterior orbital margin, XIII D spines, all spines connected by membrane, V with I spine and 5 soft rays, 13 GR (Poss 1999). This genus comprises two valid species, both of which are distributed in the Northern Indian Ocean (Psomadakis et al. 2015) and western Pacific regions (Kim et al. 2010). Among these, Snyderina guentheri is known from Indian waters (Talwar 1977).

\section{Snyderina guentheri (Boulenger, 1889)} Fig. 2D

Tetraroge guentheri Boulenger, 1889: 239, pl. XXV (type locality: Muscat, Gulf of Oman).

Snyderina guentheri (Boulenger, 1889): Talwar 1977: 580, Fig. 1. Psomadakis et al. 2015: 186.

Material. GB.38.24.45.1.1, (1, $112.16 \mathrm{~mm} \quad \mathrm{SL})$, $8^{\circ} 34^{\prime} 34^{\prime \prime} \mathrm{N}, 78^{\circ} 24^{\prime} 54^{\prime \prime} \mathrm{E}-8^{\circ} 27^{\prime} 54^{\prime \prime} \mathrm{N}, 78^{\circ} 22^{\prime} 45^{\prime \prime} \mathrm{E}$, Gulf of Mannar, 106 m, 11 October 2012.

Diagnosis. Dorsal fin spines 13, dorsal fin rays 11; anal fin spines 3, anal fin rays 7; pectoral fin rays 13; pelvic fin spine 1, pelvic fin rays 5. Total GR 13. Deep body (BD $34.33 \%$ of SL) with long head (HL $48.88 \%$ of SL). Light brown coloured with densely arranged bright red spots, four irregular light brown blotches on sides. D light brown with two broad black blotches, remaining fins black.

Description. Dorsal fin spines 13, dorsal fin rays 11; anal fin spines 3 , anal fin rays 7 ; pectoral fin rays 13 ; pelvic fin spine 1, pelvic fin rays 5. Total GR 13. Body deep (BD $34.33 \%$ of SL), slender (BW 22.22\% of SL), light brown coloured with densely arranged bright red spots and four irregular light brown blotches on sides. Head long (HL $48.88 \%$ of SL) with short snout (SnL 8.67\% of SL). Mouth moderately large (UJL $15.37 \%$ of SL), gape oblique, lower jaw projecting. Jaw teeth villiform, in bands. Eyes small (ED $6.22 \%$ of SL), IOW $6.88 \%$ of SL. Chin with three pairs of sensory pores, lower lip with one pair of pores. Lacrimal bone with short downward pointing spine and long posterior spine reaching behind middle of eye. Sub-orbital ridge strong. Pre-opercle with one backwardly directed spine. Scales minute, granular. Lateral line complete. D origin above middle of eye (PDL $9.47 \%$ of SL). D low (longest D spine 26.79\% of SL; longest D ray $25.86 \%$ of SL), D base very long ( $89.63 \%$ of SL), membranes between spines incised up to mid height; colouration light brown with bright red spots 
and two broad black blotches, first between bases of 6-9 spines, second on soft rayed portion. P origin under fifth D spine (PPL $33.23 \%$ of SL). P long (longest $\mathrm{P}$ ray $35.66 \%$ of SL), reaches beyond A origin, middle rays longest, $\mathrm{P}$ base short $(10.70 \%$ of SL). V origin slightly posterior to pectoral insertion. V short (V spine $18.76 \%$ of SL; longest $\mathrm{V}$ ray $23.54 \%$ of $\mathrm{SL}$ ), not reaching A origin. A origin under last D spine (PAL $64.40 \%$ of SL). A short (longest A spine $22.71 \%$ of SL; longest A ray $23.18 \%$ of SL), A base long (29.87\% of SL). Caudal peduncle long (CPL 10.43\% of SL), slender (CPW $1.91 \%$ of SL), moderately deep (CPD $7.74 \%$ of SL). C long (33.88\% of SL). P, V, A, C black.

Distribution. Previously known from Gulf of Aden, Gulf of Oman, Pakistan (Psomadakis et al. 2015) and southwest coast of India (Talwar 1977). This specimen represents the first record off the East coast of India, and the first outside the known geographical range.

Remarks. The presently described specimen was compared with recent descriptions of Snyderina guentheri (see Talwar 1977) and S. yamanokami (see Kim et al. 2010). This specimen closely resembles $S$. guentheri in morphometric attributes, fin counts and body colouration. On the other hand, S. yamanokami has a deeper body (BD $44.9 \%$ of SL) with longer head (HL $37.6 \%$ of SLKim et al. 2010). Moreover, in S. yamanokami, pectoral, pelvic, anal and caudal fins are light pink coloured with large red spots and small black spots; distinct black blotch present in the anterior part of lateral line above pectoral fin (Kim et al. 2010).

\section{Order Perciformes Bleeker, 1859}

Family Acropomatidae Gill, 1893

Genus Acropoma Temminck et Schlegel, 1843

Acropoma Temminck et Schlegel, 1843: 31 (type species: Acropoma japonicum Günther, 1859, by subsequent monotypy).

Remarks. Acropoma is distinguished from closely related genera in the position of anus closer to $\mathrm{V}$ origin than $\mathrm{A}$ origin, and the presence of luminescent organ between the pelvic fins (Okamoto 2014). This genus comprises six valid species, all of which are distributed in the IndoWest Pacific regions (Okamoto 2014). Among these, two species namely Acropoma japonicum and Acropoma argentistigma Okamoto et Ida, 2002 are known from the Indian waters (Okamoto 2014).

\section{Acropoma japonicum Günther, 1859}

Fig. 2E

Acropoma japonicum Günther, 1859: 250 (type locality: Japanese Sea). Smith and Heemstra 1986: 562, fig. 176.1. Synagrops splendens Lloyd, 1909: 159.

Material. GB.31.2.1.4.1, (1, $87.70 \quad \mathrm{~mm} \quad \mathrm{SL})$, $8^{\circ} 34^{\prime} 34^{\prime \prime} \mathrm{N}, 78^{\circ} 24^{\prime} 54^{\prime \prime} \mathrm{E}-8^{\circ} 27^{\prime} 54^{\prime \prime} \mathrm{N}, 78^{\circ} 22^{\prime} 45^{\prime \prime} \mathrm{E}$, Gulf of Mannar, 106 m, 11 October 2012.

Diagnosis. First dorsal fin spines 7; second dorsal fin spine 1 , second dorsal fin rays 9; anal fin spines 3, anal fin rays 7; pectoral fin rays 16; pelvic fin spine 1 , pelvic fin rays 5. Luminous gland U-shaped, extends between the pelvic fins, anterior end commences before $\mathrm{V}$ origin.
Description. First dorsal fin spines 7; second dorsal fin spine 1, second dorsal fin rays 9; anal fin spines 3 , anal fin rays 7 ; pectoral fin rays 16 ; pelvic fin spine 1 , pelvic fin rays 5. Total GR 15. Body slender (BD 34.18\% of SL, BW 14.82\% of SL), head, dorsal and caudal fins pinkish, lateral sides and lower fins silvery, covered with deciduous scales. Head large (HL $45.09 \%$ of SL, HW $15.05 \%$ of SL, HH $27.41 \%$ of SL). Mouth large (UJL $17.01 \%$ of SL; LJL $16.01 \%$ of SL), gape strongly oblique. Jaw teeth caniniform, upper jaw with pair of enlarged canines. Eye (ED $10.83 \%$ of SL) larger than snout (SnL 9.14\% of SL), IOW $7.71 \%$ of SL, post-orbital length $24.33 \%$ of SL. D origin posterior to pectoral fin insertion ( $\mathrm{PD}_{1} \mathrm{~L} 40.41 \%$ of $\mathrm{SL}$ ). $\mathrm{D}_{1}$ low, spinous (longest $\mathrm{D}_{1}$ spine $19.18 \%$ of SL), $\mathrm{D}_{1}$ base short (16.32\% of SL). $\mathrm{D}_{2}$ origin far posterior to level of anus ( $\mathrm{PD}_{2} \mathrm{~L} 64.47 \%$ of $\mathrm{SL}$ ). $\mathrm{D}_{2}$ low ( $\mathrm{D}_{2}$ spine $4.74 \%$ of SL; longest $\mathrm{D}_{2}$ ray $14.29 \%$ of SL), $\mathrm{D}_{2}$ base short $(16.10 \%$ of SL). P long (longest $\mathrm{P}$ ray $30.47 \%$ of SL), transparent. $\mathrm{V}$ origin at level of pectoral insertion (PVL $36.12 \%$ of SL). V short (V spine $11.89 \%$ of SL; longest $\mathrm{V}$ ray $17.91 \%$ of SL). Anus blackish, immediately behind V origin (pre-anus length $42.65 \%$ of SL). Luminous gland short (14.97\% of SL), U-shaped, located between pelvic fins, anterior end commences shortly before $\mathrm{V}$ origin. A origin well behind anus (PAL $69.85 \%$ of SL). A low (longest A spine $8.95 \%$ of SL; longest A ray $13.66 \%$ of SL), A base short (11.22\% of SL). Lower flanks extending from isthmus to A black; breast and lower flanks dotted with several rows of chromatophores. Caudal peduncle elongate (CPL 16.47\% of SL), deep (CPD 18.18\% of SL). C forked, short (21.03\% of SL).

Distribution. Previously known from east coast of Africa to Japan and Australia (Fischer and Bianchi 1984). In the Indian region, Acropoma japonicum was previously reported off the west coast of India (Fischer and Bianchi 1984). This specimen represents the first record off the east coast of India.

Remarks. The identification of the presently described specimen following the dichotomous key to species of the genus Acropoma (see Okamoto 2014) revealed that in the first step, the specimen differed from Acropoma lecorneti Fourmanoir, 1988 in having an elongated luminous gland (O-shaped in the latter species). In the second step, the specimen differs from two species, Acropoma boholensis Yamanoue et Matsuura, 2002 and Acropoma hanedai Matsubara, 1953 in having U-shaped luminous gland (in the latter two species, the anterior ends of the gland extend to isthmus). In the third step, it differs from Acropoma profundum Okamoto, 2014 in having the posterior ends of the luminous gland extending slightly beyond anus, but distant from A origin (in the latter species, posterior end extend close to A origin). In the fourth step, the specimen keys out as $A$. japonicum owing to anterior end of luminous gland placed slightly in advance of $\mathrm{V}$ origin; in $A$. argentistigma the front edge of luminous gland commences at $\mathrm{V}$ origin. 
Family Lethrinidae Bonaparte, 1831

Genus Gymnocranius Klunzinger, 1870

Gymnocranius Klunzinger, 1870: 764 (type species: Dentex rivulatus Rüppell, 1838, by monotypy).

Remarks. Gymnocranius is distinguished from closely related genera in having scaly cheek, smooth maxilla, D and A fins with 10 soft rays and pointed C lobes (Carpenter and Allen 1989). This genus comprises ten valid species, all of which are distributed in the Indo-Pacific regions (Carpenter and Allen 1989, Borsa et al. 2010, 2013). Among these, three species namely Gymnocranius elongatus; Gymnocranius grandoculis (Valenciennes, 1830); and Gymnocranius griseus (Temminck et Schlegel, 1843) are known from the Indian waters (Rao et al. 2000).

\section{Gymnocranius elongatus Senta, 1973}

Fig. $2 \mathrm{~F}$

Gymnocranius elongatus Senta, 1973: 135, 4 figs (type locality: Sarawak state, Borneo, East Malaysia, $3^{\circ} 31^{\prime}-$ $\left.3^{\circ} 37^{\prime} \mathrm{N}, 110^{\circ} 15^{\prime}-110^{\circ} 23^{\prime} \mathrm{E}, 67-74 \mathrm{~m}\right)$. Carpenter and Allen 1989: 23, fig. 48, pl. I, 3.

Material. GB.31.86.2.8, (1, $116.85 \mathrm{~mm} \quad \mathrm{SL})$, $8^{\circ} 49^{\prime} 22^{\prime \prime} \mathrm{N}, 78^{\circ} 32^{\prime} 38^{\prime \prime} \mathrm{E}-8^{\circ} 45^{\prime} 57^{\prime \prime} \mathrm{N}, 78^{\circ} 28^{\prime} 43^{\prime \prime} \mathrm{E}$, Gulf of Mannar, 44 m depth, 10 July 2012.

Diagnosis. Dorsal fin spines 10, dorsal fin rays 10; anal fin spines 3 , anal fin rays 10; pectoral fin rays 13; pelvic fin spine 1, pelvic fin rays 5. LS 47. Total gill rakers 18 . Lower edge of eye crossing line joining snout tip and $\mathrm{C}$ fork. C strongly forked, median rays shorter than ED.

Description. Dorsal fin spines 10, dorsal fin rays 10; anal fin spines 3, anal fin rays 10; pectoral fin rays 13; pelvic fin spine 1, pelvic fin rays 5. LS 47. Total GR 18. Body deep (BD at D origin $43.07 \%$ of SL, BD at A origin $39.48 \%$ of SL), silver coloured along flanks and belly, back brownish. Head large (HL $35.26 \%$ of SL) with moderately large snout (SnL $10.30 \%$ of SL). Mouth moderately large, gape slightly oblique. Upper jaw with band of villiform teeth, lower jaw with slender canines in outer row, inner rows villiform. Eye large (ED 11.93\% of SL), its lower edge crossing line joining snout tip and C fork, IOW $9.70 \%$ of SL. Single brown band crossing eye, two oblique bands on nape. Scales ctenoid, seven scale rows between D origin and lateral line. D origin far posterior to head (PDL $40.42 \%$ of SL). D short (longest D spine $15.28 \%$ of SL; longest D ray $14.07 \%$ of SL), brown coloured with two prominent and one faint band across it. $\mathrm{P}$ transparent, long (longest $\mathrm{P}$ ray 26.51\% of SL), not reaching A origin. $\mathrm{V}$ origin posterior to $\mathrm{P}$ origin (PVL $36.23 \%$ of SL), $\mathrm{V}$ long (V spine $18.96 \%$ of SL; longest $\mathrm{V}$ ray $28.70 \%$ of SL). A origin at level of last D spine (PAL $64.48 \%$ of SL), A short (longest A spine $9.73 \%$ of SL; longest A ray $12.10 \%$ of SL), brown coloured. Caudal peduncle with one oblique band. C strongly forked, moderately long (32.64\% of SL) with alternating light and dark brown bands on both lobes, $\mathrm{C}$ tips reddish; median rays shorter than ED.

Distribution. Previously known from Japan, South China Sea, Sarawak, Andaman Sea (Senta 1973), Australia, and south-western Pacific regions (Carpenter and Allen
1989). In India, Rao et al. (2000) reported Gymnocranius elongatus from Rutland Island (South Andaman). This specimen represents the first record off the Indian mainland.

Remarks. The identification of the presently described specimen following the dichotomous key to species of the genus Gymnocranius (see Carpenter and Allen 1989) revealed that in the first step, the specimen keyed out as G. elongatus owing to lower edge of eye crossing line joining snout tip and $\mathrm{C}$ fork, and strongly forked $\mathrm{C}$ with median rays shorter than ED. On the other hand, in the seven other congeners represented in this key (Gymnocranius euanus (Günther, 1879); Gymnocranius audleyi Ogilby, 1916; Gymnocranius frenatus Bleeker, 1873; "Gymnocranius sp."; G. griseus; Gymnocranius microdon (Bleeker, 1851); and G. grandoculis), the lower edge of eye is distinctly above line joining snout tip and $\mathrm{C}$ fork. Additionally, these species possess moderately forked $\mathrm{C}$ with median rays longer than ED. A recent taxonomic paper (Borsa et al. 2013) re-described "Gymnocranius sp." of Carpenter and Allen (1989) as Gymnocranius satoi Borsa, Béarez, Paijo et Chen, 2013.

The comparison of the presently described specimen with two more recently described species, Gymnocranius oblongus Borsa, Béarez et Chen, 2010 (see Borsa et al. 2010) and Gymnocranius superciliosus Borsa, Béarez, Paijo et Chen, 2013 (see Borsa et al. 2013) revealed that it differed from the latter two species in lower edge of eye crossing line joining snout tip and C fork. Moreover, it differed from Gymnocranius superciliosus Borsa, Béarez, Paijo et Chen, 2013 in having pointed C lobes. It is noteworthy that the $\mathrm{C}$ lobes of $G$. oblongus juveniles are similar to those of $G$. elongatus, whereas adults have rounded $\mathrm{C}$ lobes.

\section{Family Pomacentridae Bonaparte, 1831 Genus Pomacentrus Lacépède, 1802}

Pomacentrus Lacépède, 1802: 505 (type species: Chaetodon pavo Bloch, 1787, by subsequent designation). Remarks. Pomacentrus is distinguished from closely related genera in having comparatively slender body $(\mathrm{BD}<3.0$ times in SL) with fewer than 35 large scales in longitudinal series, anterior jaw teeth in double series, pre-opercle with serrate posterior margin (Allen 2001). This genus comprises 73 valid species, all of which are distributed in the Indo-Pacific region (Froese and Pauly 2016). Among these, 17 species namely Pomacentrus albicaudatus Baschieri-Salvadori, 1955; Pomacentrus alleni Burgess, 1981; Pomacentrus amboinensis Bleeker, 1868; Pomacentrus brachialis Cuvier, 1830; Pomacentrus caeruleus Quoy et Gaimard, 1825; Pomacentrus chrysurus Cuvier, 1830; Pomacentrus indicus Allen, 1991; Pomacentrus lepidogenys Fowler et Bean, 1928; Pomacentrus littoralis Cuvier, 1830; Pomacentrus moluccensis Bleeker, 1853; Pomacentrus nagasakiensis Tanaka, 1917; Pomacentrus pavo (Bloch, 1787); Pomacentrus philippinus Evermann et Seale, 1907; Pomacentrus polyspinus Allen, 1991; Pomacentrus proteus Allen, 1991; P. similis; and Pomacentrus 
tripunctatus Cuvier, 1830 are known from the Indian waters (Rao et al. 2000, Sluka 2013, Devi et al. 2015, Sorenson et al. 2014).

\section{Pomacentrus similis Allen, 1991}

Fig. 2G

Pomacentrus similis Allen, 1991: 232 (type locality: Trincomalee, Sri Lanka, $8^{\circ} 30^{\prime} \mathrm{N}, 81^{\circ} 06^{\prime} \mathrm{E}, 3 \mathrm{~m}$ depth). Liu et al. 2013: 9, fig. 1D.

Materials. GB.31.122.22.22, (3, $51.65 \mathrm{~mm}, 42.64 \mathrm{~mm}$, $38.40 \mathrm{~mm}$ SL), $8^{\circ} 42^{\prime} 44^{\prime \prime} \mathrm{N}, \quad 78^{\circ} 23^{\prime} 56^{\prime \prime} \mathrm{E}-8^{\circ} 43^{\prime} 50^{\prime \prime} \mathrm{N}$, $78^{\circ} 30^{\prime} 56^{\prime \prime} \mathrm{E}$, Gulf of Mannar, 32 m, 10 July 2012.

Diagnosis. Dorsal fin spines 13, dorsal fin rays 14; anal fin spines 2 , anal fin rays 11 ; pectoral fin rays 17 ; pelvic fin spine 1, pelvic fin rays 5. Total GR 18. Body slender, bright blue coloured, covered with 25-30 large ctenoid scales in longitudinal series. Snout with horizontal black stripe. D, A, and V blue, P transparent yellow, C bright yellow.

Description. Dorsal fin spines 13, dorsal fin rays 14; anal fin spines 2 , anal fin rays 11; pectoral fin rays 17 ; pelvic fin spine 1, pelvic fin rays 5 . Total GR 18 . Body slender (BW 14.28\%-16.43\% of SL), deep (BD 34.69\%-37.77\% of SL), compressed, bright blue coloured, covered with large ctenoid scales (about 25-30 in longitudinal series). Head small (HL $27.45 \%-28.85 \%$ of SL), with large eye (ED $9.90 \%-10.48 \%$ of SL), IOW $7.60 \%-8.09 \%$ of SL. Mouth small (UJL $7.49 \%-10.05 \%$ of SL), gape oblique. Jaw teeth elongate incisiform, anterior teeth biserial. Snout short ( $\mathrm{SnL} 4.03 \%-6.52 \%$ of SL), with horizontal black streak. Cheek scaly, pre-opercle with strongly serrate posterior margin. Scales ctenoid, five scale rows between D origin and lateral line. D origin above second lateral line scale (PDL 29.55\%-30.63\% of SL). D long (first D spine $5.53 \%-6.41 \%$ of SL; seventh D spine $11.85 \%-12.66 \%$ of SL; last D spine $12.90 \%-14.17 \%$ of SL; longest D ray $16.04 \%-21.34 \%$ of SL), D fin base (59.01\%-63.62\% of SL) covered with low scaly sheath. A origin under 10th or 11th dorsal fin spine (PAL 60.18\%$63.62 \%$ of SL). A short (first A spine $7.98 \%-9.45 \%$ of SL; second A spine $13.93 \%-15.55 \%$ of SL; longest A ray $14.85 \%-18.86 \%$ of SL), A fin base $(22.81 \%-27.56 \%$ of SL) covered with low scaly sheath. P moderately long (longest $\mathrm{P}$ ray $23.33 \%-25.98 \%$ of SL), transparent yellow. $\mathrm{V}$ origin at level of P origin (PVL 26.46\%-33.35\% of SL). V moderately long (V spine $13.09 \%-16.82 \%$ of SL; longest V ray $25.34 \%-30.98 \%$ of SL). D, A, and V blue. Caudal peduncle short (CPL 6.06\%-9.11\% of SL) and moderately deep (CPD 12.50\%-13.69\% of SL). C forked, moderately long $(25.47 \%-28.89 \%$ of SL), bright yellow.

Distribution. Previously known from Sri Lanka (Allen 1991, Liu et al. 2013), Andaman Sea (Allen 1991), and Narcondam Island, India (Sorenson et al. 2014). This specimen represents the first record off the Indian mainland.

Remarks. Pomacentrus similis belongs to the "Pomacentrus coelestis complex", which also includes P. alleni; Pomacentrus auriventris Allen, 1991; P. caeruleus; Pomacentrus coelestis Jordan et Starks,
1901; and Pomacentrus micronesicus Liu, Ho et Dai, 2013 (see Liu et al. 2013). Within this species-complex, $P$. similis is distinguishable from its congeners in having blue colouration on the entire body, dorsal, pelvic, and anal fins, transparent yellow pectoral fin, and yellow caudal fin. In contrast, the other species possess blue colouration on the anterior and dorsal part of the body, and varying proportions of yellow colouration on the posterior and ventral parts of the body, soft dorsal and anal fins (Liu et al. 2013).

\section{Genus Pristotis Rüppell, 1838}

Pristotis Rüppell, 1838: 128 (type species Pristotis cyanostigma Rüppell, 1838, by monotypy).

Remarks. Pristotis is distinguished from closely related genera in having comparatively slender body (depth less than 3.0 times in SL) with less than 35 large scales in longitudinal series, scaly head, teeth in single series in each jaw, pre-opercle with serrate posterior margin (Allen 2001). This genus comprises two valid species, both of which distributed in the Indo-West Pacific regions (Froese and Pauly 2016). Among these, Pristotis obtusirostris (Günther, 1862) is known from the Indian waters (Froese and Pauly 2016).

\section{Pristotis cyanostigma Rüppell, 1838 Fig. $2 \mathrm{H}$}

Pristotis cyanostigma Rüppell, 1838: 128, pl. 31, fig. 5 (type locality: off Massawa, Eritrea, Red Sea).

Materials. GB.31.122.20.28, (1, 87.04 mm SL), bycatch landed at Tuticorin fisheries jetty, 12 October 2012, $(1,68.94 \mathrm{~mm} \mathrm{SL}), 8^{\circ} 47^{\prime} 49^{\prime \prime} \mathrm{N}, 7^{\circ} 23^{\prime} 07^{\prime \prime} \mathrm{E}-8^{\circ} 45^{\prime} 47^{\prime \prime} \mathrm{N}$, $78^{\circ} 17^{\prime} 15^{\prime \prime} \mathrm{E}$, Gulf of Mannar, 16 m, 13 March 2013.

Diagnosis. Dorsal fin spines 13, dorsal fin rays 13; anal fin spines 2 , anal fin rays 14 ; pectoral fin rays 16 ; pelvic fin spine 1 , pelvic fin rays 5 . Total GR 24. Body pale grey, scales large, ctenoid, 32-33 in longitudinal series; each scale with blue spot. Head medium-sized with serrate subopercular margin.

Description. Dorsal fin spines 13, dorsal fin rays 13; anal fin spines 2, anal fin rays 14; pectoral fin rays 16; pelvic fin spine 1, pelvic fin rays 5 . Total GR 24. Body slender (BW 17.76\%-18.00\% of SL), deep (BD 38.80\%$41.02 \%$ of SL), olive grey coloured on head and dorsal surface, flanks light olive green, belly drab grey. Head small (HL $24.86 \%-26.49 \%$ of SL), with moderately large eye (ED $7.96 \%-9.11 \%$ of SL), IOW $8.54 \%-9.01 \%$ of SL. Mouth small (UJL $12.04 \%-12.56 \%$ of SL), gape almost vertical. Jaw teeth incisiform anteriorly, lateral teeth conical. Snout short (length $3.40 \%-5.13 \%$ of SL). Cheek scaly, pre-opercle with serrate sub-opercular margin. Operculum with one strong spine. Scales ctenoid (32-33 in longitudinal series), four scale rows between D origin and lateral line; each dermal scale with a conspicuous blue spot. D origin in advance of pectoral insertion (PDL 24.91\%-28.95\% of SL). D long (longest D spine $13.08 \%-14.06 \%$ of SL; longest D ray $17.81 \%-20.27 \%$ of SL), D base long $(61.74 \%-62.12 \%$ of SL), covered with low scaly sheath. A origin under dorsal spine (PAL 56.11\%- 
$58.98 \%$ of SL). A short (longest A spine 10.67\%-11.28\% of SL; longest A ray $13.55 \%-16.99 \%$ of SL), A base short ( $28.32 \%-31.19 \%$ of SL), covered with low scaly sheath. $\mathrm{P}$ moderately long (longest $\mathrm{P}$ ray $20.15 \%-21.64 \%$ of SL), transparent; black blotch on $\mathrm{P}$ axil. V origin slightly posterior to pectoral insertion (PVL 30.30\%-32.59\% of SL). V short (V spine $11.97 \%-12.63 \%$ of SL; longest $\mathrm{V}$ ray $20.61 \%-21.98 \%$ of SL), reaching anal fin origin. Tubular lateral line terminating anterior to hind end of D soft portion. Caudal peduncle short (CPL 9.68\%-11.11\% of SL) and deep (CPD 14.87\%-16.72\% of SL). C forked (37.41\%-48.18\% of SL), olive grey coloured, uppermost ray of upper lobe filamentous.

Distribution. Previously known from the Red Sea (Rüppell 1838). This specimen represents the first record in the Indian waters, and the first outside the known geographical range.

Remarks. Pristotis cyanostigma is distinguished from its only congener, P. obtusirostris in having deeper body, longer upper jaw, slightly longer dorsal and anal rays, higher numbers of anal rays, lower number of pectoral fin rays, and scale rows across cheek, as well as irregular blue spots on snout and operculum (in P. obtusirostris, BD $34.5 \% \mathrm{SL}$, UJL $10.0 \% \mathrm{SL}$, longest $\mathrm{D}$ ray $15.3 \%$ SL, longest A ray $14.3 \%$ SL, A 12 rays, P 19 rays, 3 scale rows across cheek-Tyler 1966). Moreover, the latter species is light olive coloured with light coloured lines on D, A, and C fins (Tyler 1966).

\section{Family Labridae Cuvier, 1816}

Genus Leptojulis Bleeker, 1862

Leptojulis Bleeker, 1862: 412 (type species: Julis (Halichoeres) cyanopleura Bleeker, 1853, by original designation, monotypy).

Remarks. Leptojulis is distinguished from closely related genera in having slender body (BD 4-5 times SL) with large dermal scales and single dark mid-lateral stripe. Cheek below eye scaleless. Two pairs of anterior jaw teeth enlarged and caniniform, canines present at corner of mouth. Complete lateral line with less than 28 scales, 4 scale rows between lateral line and D origin. D with IX spines and 11-12 soft rays, A with III spines (Westneat 2001). This genus comprises five valid species, all of which are distributed in the Indo-West Pacific regions (Randall 1996). Among these, two species namely Leptojulis chrysotaenia Randall et Ferraris, 1981 and L. cyanopleura are known from Indian waters (Randall 1996).

\section{Leptojulis cyanopleura (Bleeker, 1853)}

Fig. 2I

Julis (Halichoeres) cyanopleura Bleeker, 1853: 489 (type locality: Jakarta, Java, Indonesia).

Leptojulis (Halichoeres) pyrrhogramatoides Bleeker, 1853: 490.

Leptojulis cyanopleura (Bleeker, 1853): Randall 1996: 6. Material. GB.31.78.28.24, (1, $71.44 \mathrm{~mm} \quad \mathrm{SL})$, $8^{\circ} 42^{\prime} 44^{\prime \prime} \mathrm{N}, 78^{\circ} 23^{\prime} 56^{\prime \prime} \mathrm{E}-8^{\circ} 43^{\prime} 50^{\prime \prime} \mathrm{N}, 78^{\circ} 30^{\prime} 56^{\prime \prime} \mathrm{E}$, Gulf of Mannar, 32 m, 10 July 2012.
Diagnosis. Dorsal fin spines 9, dorsal fin rays 11; anal fin spines 3 , anal fin rays 11 ; pectoral fin rays 13 ; pelvic fin spine 1, pelvic fin rays 5. LS 27. Total GR 27. Body elongate (BD 2.66 times in SL), yellow coloured with two longitudinal brown stripe on sides, upper stripe just below $\mathrm{D}$ fin and one mid-lateral stripe extending from snout to caudal peduncle. Head small (HL 4.21 times in SL). Pectoral fin short (16.04\% of HL).

Description. Dorsal fin spines 9, dorsal fin rays 11; anal fin spines 3 , anal fin rays 11; pectoral fin rays 13; pelvic fin spine 1 , pelvic fin rays 5 . Total GR 27 . Body elongate (BD $37.63 \%$ of SL), slender (BW $9.87 \%$ of SL), yellow coloured with two longitudinal brown stripes on sides, upper stripe just below dorsal fin and one mid-lateral stripe extending from snout to caudal peduncle. Head small (HL $23.75 \%$ of SL), with small eye (ED $7.75 \%$ of SL), IOW $8.50 \%$ of SL. Mouth small (UJL $6.33 \%$ of SL), terminal. Jaws with short caniniform teeth, anterior-most four teeth large canines. Snout short (SnL 6.38\% of SL). Lateral line close to dorsal fin base in its anterior twothirds, descending abruptly and continuing along midlateral stripe in its posterior one-third, scales in lateral line 27. Scales large, cycloid, two scale rows between D origin and lateral line; scale rows between stripes brownish. D origin behind head (PDL $26.37 \%$ of SL). D short (longest D spine $11.10 \%$ of SL; longest D ray $11.67 \%$ of SL), D base long (63.94\% of SL). A origin at level of first D ray (PAL $54.37 \%$ of SL), A short (longest A spine $11.66 \%$ of SL; longest A ray $10.58 \%$ of SL), A base long (34.38\% of SL). P short (longest P ray $16.04 \%$ of SL). V origin slightly behind pectoral insertion (PVL $37.63 \%$ of SL). $\mathrm{V}$ short (V spine $5.77 \%$ of SL, longest $\mathrm{V}$ ray $14.22 \%$ of SL). Caudal peduncle short (CPL $9.59 \%$ of SL) and deep (CPD $15.51 \%$ of SL). C short (14.15\% of SL), rounded. $\mathrm{D}, \mathrm{A}, \mathrm{V}$, and $\mathrm{C}$ light orange coloured, $\mathrm{P}$ transparent.

Distribution. Previously known from the Persian Gulf to Malaysia, Indonesia, New Guinea, and Australia (Randall 1996). In India, Randall (1996) reported Leptojulis cyanopleura from Vizhinjam (Kerala). This specimen represents the first record along the East coast of India.

Remarks. The identification of the presently described specimen following the dichotomous key to species of the genus Leptojulis (see Randall 1996) revealed that in the first step, the specimen differed from Leptojulis polylepis Randall, 1996 in having 27 lateral line scales (46 in the latter species). In the second step, this specimen differed from Leptojulis lambdastigma Randall et Ferraris, 1981 in having short $\mathrm{P}$ fin, D and A with 11 soft rays, and absence of V-shape mark on nape. On the other hand, L. lambdastigma possesses longer P fin, D and A with 12 soft rays, and V-shaped mark on nape. In the third step, it differed from L. chrysotaenia in having an elongate body (BD 2.66 times in SL and smaller head (HL 4.21 times in SL). In the fourth step, the specimen keyed out as L. cyanopleura owing to 27 gill rakers and absence of dark spot on $\mathrm{C}$ base. The other species in the fourth step, Leptojulis urostigma Randall, 1996 possesses 16-18 gill rakers and dark brown spot on $\mathrm{C}$ base. 


\section{Family Acanthuridae Bonaparte, 1835 Genus Naso Lacépède, 1801}

Naso Lacépède, 1801: 105 (type species: Naso fronticornis Lacépède, 1801, by subsequent designation).

Remarks. Naso is distinguished from closely related genera in having shallow caudal peduncle (depth 4.0-6.0 times in head length), 1-2 bony plates on either sides on caudal peduncle, D with IV-V spines, V with I spine and 3 soft rays (Randall 2001a). This genus comprises twenty species distributed in the Indo-Pacific regions (Randall 2001b, Johnson 2002, Ho et al. 2011). Among these, seven species namely Naso brachycentron (Valenciennes, 1835); Naso brevirostris (Cuvier, 1829); Naso hexacanthus (Bleeker, 1855); Naso lituratus (Forster, 1801); Naso tuberosus Lacepède, 1801; Naso unicornis (Forsskål, 1775); and Naso vlamingii (Valenciennes, 1835) are known from the Indian waters (Sluka 2013, Froese and Pauly 2016).

\section{Naso annulatus (Quoy et Gaimard, 1825)}

Fig. 2J

Priodon annulatus Quoy et Gaimard, 1825: 377 (type locality: Timor Island, Southeast Asia).

Naso herrei Smith, 1966: 647.

Naso annulatus (Quoy et Gaimard, 1825): Smith and Heemstra 1986: 819.

Material. GB.31.1.4.20, (2, $53.54 \mathrm{~mm}, 126.83 \mathrm{~mm} \mathrm{SL})$, $8^{\circ} 42^{\prime} 44^{\prime \prime} \mathrm{N}, 78^{\circ} 23^{\prime} 56^{\prime \prime} \mathrm{E}-8^{\circ} 43^{\prime} 50^{\prime \prime} \mathrm{N}, 78^{\circ} 30^{\prime} 56^{\prime \prime} \mathrm{E}$, Gulf of Mannar, 32 m, 10 July 2012.

Diagnosis. Dorsal fin spines 5, dorsal fin rays 29; anal fin spines 2 , anal fin rays 27 ; pectoral fin rays 15 ; pelvic fin spine 1, pelvic fin rays 3. Body deep (BD 2.11 times in SL). Teeth incisiform with finely serrate edges. Dorsal surface of snout angled at $54^{\circ}$ with base of snout, lacking protuberance. Dorsal surface without hump, profile beneath spinous portion of dorsal fin slightly convex. Caudal peduncle with two bony plates on either side. $\mathrm{C}$ with white posterior margin.

Description. Dorsal fin spines 5, dorsal fin rays 29; anal fin spines 2, anal fin rays 27; pectoral fin rays 15 ; pelvic fin spine 1, pelvic fin rays 3. Body deep (BD 42.21\%-47.40\% of SL), compressed (BW 14.23\%-14.52\% of SL), drab grey coloured. Head small (HL 26.44\%-29.29\% of SL) with large eye (ED $8.88 \%-11.30 \%$ of SL), IOW $8.47 \%-9.56 \%$ of SL, sub-orbital width $11.34 \%-11.69 \%$ of SL. Mouth small (UJL $5.77 \%-5.85 \%$ of SL), terminal. Jaw teeth pointed incisors, with serrate edges. Snout moderately long ( $\mathrm{SnL} 12.00 \%-12.46 \%$ of SL). Dorsal surface of snout angled at $54^{\circ}$ with base of snout, lacking protuberance. Oblique groove on side of snout extends from anterior edge of orbit half-way to mouth. Scales minute, ctenoid. Dorsal profile of back below spinous dorsal fin slightly arched. Lateral line parallel to dorsal profile of body. D origin slightly anterior to opercular margin (PDL 23.76\%$28.67 \%$ of SL). D short (first D spine $13.20 \%-16.32 \%$ of SL; second D spine $11.68 \%-16.14 \%$ of SL; fifth D spine $10.31 \%-12.48 \%$ of SL; longest D ray $12.05 \%-12.40 \%$ of SL), black coloured, D base long $(66.80 \%-66.81 \%$ of SL). A origin under fifth D spine (PAL 37.16\%-37.28\% of SL). A short (first A spine $7.17 \%-11.60 \%$ of SL; second
A spine $7.38 \%-9.53 \%$ of SL; longest A ray $9.34 \%-9.53 \%$ of SL), black coloured, A base long $(53.50 \%-54.20 \%$ of SL). P short (longest P ray $17.30 \%-19.61 \%$ of SL), transparent, its origin under operculum. $\mathrm{V}$ origin under pectoral insertion (PVL 21.85\%-24.41\% of SL). V short (V spine $10.74 \%-11.47 \%$ of SL; longest $\mathrm{V}$ ray $12.14 \%$ $14.06 \%$ of SL), grey coloured, reaching beyond A origin. Caudal peduncle short (CPL $6.76 \%-9.49 \%$ of SL), slender (CPW $4.15 \%-4.65 \%$ of SL; CPD $8.74 \%-9.59 \%$ of SL), with two keeled plates on either side. C moderately long (20.99\%-23.63\% of SL), emarginated, grey coloured, with white posterior margin; C fork short $(9.86 \%-12.57 \%$ of SL).

Distribution. Previously known from East coast of Africa (Smith and Heemstra 1986) to Hawaii (Robertson et al. 2004). This specimen represents the first record off the Indian mainland.

Remarks. The identification of the presently described specimen following the dichotomous key to species of the genus Naso (see Randall 2001b) revealed that in the first step, the specimen shared the character "two keeled plates on each side of caudal peduncle" with 14 species in the key. In the second step, this specimen differed from Naso lituratus and Naso elegans (Rüppell, 1829) in having incisiform teeth with serrated edges, grey coloured peduncular plates and absence of yellow line on head. The specimen being a juvenile could not be compared in respect of protuberance or horn on snout. Further, it differed from $N$. brachycentron in lacking dorsal hump and having slightly convex profile beneath spinous portion of dorsal fin; it differed from $N$. unicornis in having dorsal profile of snout at an angle of $54^{\circ}$ and grey peduncular plates. Subsequently, it keyed out as $N$. annulatus owing to $\mathrm{V}$ dorsal spines, plain grey coloured body and $\mathrm{C}$ with white posterior margin.

The comparison of the presently described specimen with three species not included in Randall's key namely Naso mcdadei Johnson, 2002; Naso tonganus (Valenciennes, 1835) (see Johnson 2002); and Naso tergus Ho, Shen et Chang, 2011 (see Ho et al. 2011) revealed that it differed from $N$. tergus in having five D spines (six in the latter species). Further, it differed from the latter three species in having a deeper body, longer head, larger eye and longer $\mathrm{P}$ fin. The morphometric proportions of BD, HL, ED, and P lengths for N. mcdadei are $33.6 \%-38.4 \%, 20.8 \%-24.4 \%, 4.2 \%-7.0 \%$, and $13.1 \%-16.5 \%$, respectively; for $N$. tonganus, $34.4 \%-$ $41.1 \%, 20.8 \%-26.4 \%, 4.4 \%-6.0 \%$, and $13.7 \%-17.2 \%$, respectively; for $N$. tergus, $34.4 \%-36.8 \%, 24.6 \%-26.6 \%$, $6.3 \%-7.2 \%$, and $14.0 \%-15.7 \%$, respectively.

\section{Naso thynnoides (Valenciennes, 1835)}

Fig. $2 \mathrm{~K}$

Axinurus thynnoides Cuvier, 1829: 225 (nomen nudum)

Axinurus thynnoides Valenciennes in Cuvier et Valenciennes, 1835: 299, pl. 293 (type locality: Dorey Harbor, Papua New Guinea).

Naso thynnoides (Valenciennes, 1835): Smith and Heemstra 1986: 822. Randall 1994: 118, figs. 1, 2, pl. IA-B. 
Material. GB.31.1.5.22, (1, $105.05 \quad \mathrm{~mm} \quad \mathrm{SL})$, $8^{\circ} 42^{\prime} 44^{\prime \prime} \mathrm{N}, 78^{\circ} 23^{\prime} 56^{\prime \prime} \mathrm{E}-8^{\circ} 43^{\prime} 50^{\prime \prime} \mathrm{N}, 78^{\circ} 30^{\prime} 56^{\prime \prime} \mathrm{E}$, Gulf of Mannar, 32 m, 10 July 2012.

Diagnosis. Dorsal fin spines 4, dorsal fin rays 29; anal fin spines 2, anal fin rays 27; pectoral fin rays 16; pelvic fin spine 1, pelvic fin rays 3, total GR 25. Body slender (BD 3.25 times in SL). Snout profile convex; oblique groove on side of snout extends from anterior edge of orbit half-way to mouth. Inter-orbital region and internarial space flat. Caudal peduncle with one bony plate on either side.

Description. Dorsal fin spines 4, dorsal fin rays 29; anal fin spines 2, anal fin rays 27; pectoral fin rays 16 ; pelvic fin spine 1, pelvic fin rays 3, total GR 25. Body less deep (BD $30.80 \%$ of SL), compressed (BW $11.46 \%$ of SL), drab grey coloured, with lighter patches on upper half of body. Head small (HL $25.36 \%$ of SL), anterior profile convex, lacking protuberance. Eye moderately large (ED 8.21\% of SL), IOW $7.90 \%$ of SL, sub-orbital width $9.46 \%$ of SL. Mouth small (UJL $2.98 \%$ of SL), terminal. Jaw teeth pointed incisors, with serrate edges. Snout moderately long (SnL $11.56 \%$ of SL). Oblique groove on side of snout extending from anterior edge of orbit half-way to mouth. Inter-orbital region and inter-narial space flat. Scales minute, ctenoid. Dorsal profile of back below spinous dorsal fin slightly flat. Lateral line parallel to dorsal profile of body. D origin slightly anterior to opercular margin (PDL 26.08\% of SL). D short (first D spine $6.95 \%$ of SL; second D spine $10.20 \%$ of SL, longest D ray $9.39 \%$ of SL), black coloured, D base long (63.10\% of SL). A origin under fourth D spine (PAL $34.88 \%$ of SL). A short (first A spine broken; second A spine $5.95 \%$ of SL; longest A ray $9.12 \%$ of SL), black coloured, A base long (54.26\% of SL). P short (longest P ray $15.75 \%$ of SL), transparent, $P$ origin under operculum. V origin under pectoral insertion (PVL 24.08\% of SL). V short (V spine $9.25 \%$ of SL; V longest ray $9.81 \%$ of SL), grey coloured, reaching beyond A origin. Caudal peduncle short (CPL $8.86 \%$ of SL), slender (CPW $3.48 \%$ of SL; CPD 5.18\% of SL), with one keeled plate on either side. C moderately long (19.65\% of SL), emarginated, grey coloured, with white posterior margin; C fork short ( $6.32 \%$ of SL).

Distribution. East coast of Africa to Japan, Solomon Islands, and Caroline Islands (Randall 1994). This specimen represents the first record in the Indian waters.

Remarks. The identification of the presently described specimen following the dichotomous key to species of the genus Naso (see Randall 2001b) revealed that in the first step, the specimen shared the character "one keeled plate on each side of caudal peduncle" with three species in the key. In the second step, this specimen differed from Naso minor (Smith, 1966) in having four dorsal spines (five in the latter species) and long groove on side of snout extending from near edge of orbit halfway to mouth (in $N$. minor, the groove is shorter). In the third step, it keys out as $N$. thynnoides owing to slender body (BD 3.25 times in SL), convex snout, and flat median zone on anterior inter-orbital and inter-narial spaces. It differs from Naso caeruleacauda Randall, 1994 with deeper body
(BD 2.75-2.80 times in SL), straight snout, and strongly convex inter-orbital and inter-narial spaces.

The presently described specimen differed slightly from Randall's description of $N$. thynnoides (see Randall 1994) in respect of three morphometric ratios (SL/BD, SL/HL, and $\mathrm{HL} / \mathrm{SnL}$ ). The observed ratios were $3.25,3.94$, and 2.19, respectively as compared to $2.80-3.20,4.05-4.20$, and 1.95-2.10, respectively reported by Randall (1994).

\section{Order Tetraodontiformes Berg, 1937 \\ Family Monacanthidae Nardo, 1842 \\ Genus Pseudalutarius Bleeker, 1865}

Pseudalutarius Bleeker, 1865: 183 (type species: Aluteres nasicornis Temminck et Schlegel, 1850, by monotypy).

Remarks. Pseudalutarius is a monotypic genus distinguished from closely related genera in the forward position of $\mathrm{D}_{1}$. It is distributed from the eastern coasts of Africa to southern Japan, northern Australia and New Caledonia (Matsuura 2015). The presently reported observation constitutes the first record from Indian waters.

\section{Pseudalutarius nasicornis (Temminck et Schlegel, 1850) \\ Fig. 2L}

Alutera nasicornis Temminck et Schlegel, 1850: 293, pl. CXXXI, fig. 2 (type locality: Nagasaki, Japan).

Pseudalutarius nasicornis (Temminck et Schlegel, 1850): Smith and Heemstra 1986: 886, fig. 264.12.

Material. GB.43.4.15.8, (1, $55.23 \quad \mathrm{~mm} \quad \mathrm{SL})$, $8^{\circ} 47^{\prime} 49^{\prime \prime} \mathrm{N}, 78^{\circ} 23^{\prime} 07^{\prime \prime} \mathrm{E}-8^{\circ} 45^{\prime} 47^{\prime \prime} \mathrm{N}, 78^{\circ} 17^{\prime} 15^{\prime \prime} \mathrm{E}$, Gulf of Mannar, 16 m, 13 March 2013.

Diagnosis. Body slender, compressed, off white coloured with two longitudinal brown bands along sides. $\mathrm{D}_{1}$ positioned anterior to eye. $\mathrm{V}$ rudiment concealed underneath skin.

Description. Dorsal fin spines 2, dorsal fin rays 43; anal fin rays 41 ; pectoral fin rays 12 . Body less deep (BD $28.28 \%$ of SL), compressed (BW $10.03 \%$ of SL), off white coloured with two longitudinal brown bands along sides. Head moderately large (HL $28.41 \%$ of SL), gently sloping forward. Mouth small, terminal. Jaw teeth long, incisiform. Eye moderately large (ED $6.97 \%$ of SL), IOW $7.62 \%$ of SL. Gill slits long ( $4.83 \%$ of SL). Snout long (SnL $18.74 \%$ of SL). Scales minute, prickly, embedded in skin. Two dorsal fins, $\mathrm{D}_{1}$ origin anterior to eye (snout to dorsal spine distance $11.55 \%$ of SL). Lower jaw to $\mathrm{V}$ rudiment distance $44.58 \%$ of SL. V rudiment concealed under skin. $\mathrm{D}_{1}$ spine extremely long ( $29.17 \%$ of SL); inter-dorsal space $35.58 \%$ of SL. D base moderately long (39.72\% of SL); longest D ray $5.18 \%$ of SL. A origin posterior to $\mathrm{D}_{2}$ origin (PAL $53.78 \%$ of SL). A base moderately long (38.46\% of SL), longest A ray $7.13 \%$ of SL. P transparent, short (longest P ray $7.10 \%$ of SL). Caudal peduncle short (CPL $5.18 \%$ of SL), slender (CPD $6.84 \%$ of SL). C moderately long (14.54\% of SL), prominently dark brown.

Distribution. East Africa to southern Japan, northern Australia and New Caledonia (Matsuura 2015). This specimen represents the first record in the Indian waters. 
Remarks. Pseudalutarius nasicornis is the only known representative of the genus Pseudalutarius. It differs from other monacanthids in having a long, slender body and $\mathrm{D}_{1}$ placed well in advance of the eye (Hutchins 2001).

\section{Family Tetraodontidae Bonaparte, 1831 Genus Lagocephalus Swainson, 1839}

Lagocephalus Swainson, 1839: 194, 328 (type species: Lagocephalus lagocephalus Linnaeus, 1758, by subsequent designation).

Remarks. Lagocephalus is distinguished from closely related genera in having lower half of body silver white, contrasted to dark dorsal half, terminal mouth, indistinct chin, nasal organ covered by small sac with two nostrils, top of $\mathrm{P}$ base below lower margin of eye, D and A with 9-10 soft rays, raised skin fold along lower side of caudal peduncle (Matsuura 2001). This genus comprises 11 species with circum-global distribution. Among these, three species namely Lagocephalus inermis (Temminck et Schlegel, 1850); Lagocephalus lunaris (Bloch et Schneider, 1801); and Lagocephalus spadiceus (Richardson, 1845) are known from the Indian waters (Froese and Pauly 2016).

\section{Lagocephalus suezensis Clark et Gohar, 1953} Fig. 2M

Lagocephalus suezensis Clark et Gohar, 1953: 56, fig. 16 (type locality: Suez, Egypt, Gulf of Suez).

Material. GB.43.6.15.10, (1, $124.42 \mathrm{~mm} \mathrm{SL),} \mathrm{by-catch}$ landed at Tuticorin fisheries jetty, 15 March 2013.

Diagnosis. Body sub-cylindrical, dorsal and upper half of lateral surfaces greenish yellow covered with unequal sized dark spots, lateral silver band extending from mouth to $\mathrm{C}$ fin. Prickly area on dorsal surface commencing posterior to eye, extending up to D origin. Raised skin fold extending from chin to caudal fin base.

Description. Dorsal fin rays 10; anal fin rays 9; pectoral fin rays 15 . Body sub-cylindrical (BW at $\mathrm{P}$ base $16.20 \%$ of SL), shallow (maximum BD $17.77 \%$ of SL; BD at end of D base $9.93 \%$ of SL), dorsal and upper half of lateral surfaces greenish yellow covered with unequal sized dark spots, silver band on lower flanks extending from mouth to caudal fin, ventral surface whitish. Head moderately large (HL 29.98\% of SL). Mouth small, terminal (width $6.22 \%$ of SL; upper lip depth $2.44 \%$ of SL). Teeth fused to form two plates in each jaw, with anterior beak-like projection. Snout long (SnL $12.72 \%$ of SL), snout to anterior edge of nasal organ distance $6.94 \%$ of SL. Nasal organ extremely small (length $0.94 \%$ of SL), located in depression, covered by small sac with two nostrils; posterior edge of nasal organ to anterior edge of eye distance $4.30 \%$ of SL. Eye moderately large (ED $10.42 \%$ of SL), IOW $4.73 \%$ of SL, preceded by silvery patch. Gill slit long ( $8.33 \%$ of SL). Patch of spinules on dorsal surface commencing posterior to eye, extending up to D origin. Two lateral lines. D origin at level of anus (snout to D origin distance $66.87 \%$ of SL). D base short (6.33\% of SL); longest D ray $11.84 \%$ of SL. Raised skin on lateral side fold extending from chin to $\mathrm{C}$ base. Patch of spinules on belly extending posteriorly up to cloaca. A origin posterior to D origin (snout to A origin distance $68.16 \%$ of SL). A base short (6.27\% of SL), longest A ray $11.14 \%$ of SL. P transparent, short (longest P ray $16.50 \%$ of SL). Caudal peduncle long (CPL 23.02\% of SL), tapering (CPD 10.42\% of SL). C emarginate, moderately long (17.70\% of SL).

Distribution. Throughout the Indo-Pacific regions up to Japan (Iwatsubo et al. 2009). This species is a Lessepsian migrant to the Mediterranean with known occurrences off Lebanon, Israel, Turkey, Syria, Greece, Cyprus, Libya, and Egypt (Farrag et al. 2016). This specimen represents the first record in the Indian waters.

Remarks. Two out of 11 valid species in the genus Lagocephalus - L. suezensis and Lagocephalus sceleratus (Gmelin, 1789) - are characterized by the presence of two lateral lines and greyish spots on greenish dorsal surface. Among these, L. suezensis attains a smaller size $(18.59 \mathrm{~cm}$ SL-Iwatsubo et al. 2009) as compared to L. sceleratus (110.00 cm SL-Froese and Pauly 2016). In addition, it has a raised skin fold along lower side of caudal peduncle (absent in L. sceleratus), and unequal-sized grey spots on the dorsal surface (equal-sized spots in L. sceleratusFarrag et al. 2016). Iwatsubo et al. (2009) reveal that morphometric ratios and meristics of $L$. suezensis are wider in range as compared to those of L. sceleratus.

\section{Key to the fishes from Gulf of Mannar identified during the presently reported study}

1A. Body covered by placoid scales. Mouth angular, labial furrows long. Five pairs of uncovered, slit-like external gill openings on head, last pair behind pectoral fin origin; spiracle smaller than eye. Dorsal fins spineless, $\mathrm{D}_{1}$ base $<0.7$ times caudal fin length. Caudal fin asymmetrical, terminal lobe one-thirds in length of dorsal caudal fin margin, caudal peduncle without keels................... Hypogaleus hyugaensis 1B. Body covered by ctenoid or cycloid scales. Labial furrows absent. One pair of external gill openings on head anterior to pectoral fin and covered by operculum; spiracle absent. Fins supported by spines and segmented rays. Caudal fin symmetrical.

2A. Body extremely long, slender (BD $<5 \%$ of SL), covered with fine brown reticulation; posterior nostril not contiguous with supra-orbital pore; lateral line pores $<5$, located anterior to gill opening; dorsal and anal fins extremely low ridges restricted to caudal tip; Pectoral fin absent ....................................Uropterygius micropterus 2B. Body moderately long, $\mathrm{BD}>15 \%$ of SL; lateral line pores/ scales $>14$, located posterior to gill opening; dorsal and anal fins completely developed; pectoral fin present 3

3A. Pelvic fins present 4

3B. Pelvic fins absent 12

4A. Head with ridges and spines, sub-orbital stay extends posteriorly up to the pre-operculum and firmly attached to it; dorsal fin single, notched, with XIII spines; pectoral fin elongated, reaches beyond anal fin origin; anal fin with III spines; caudal fin usually rounded. 

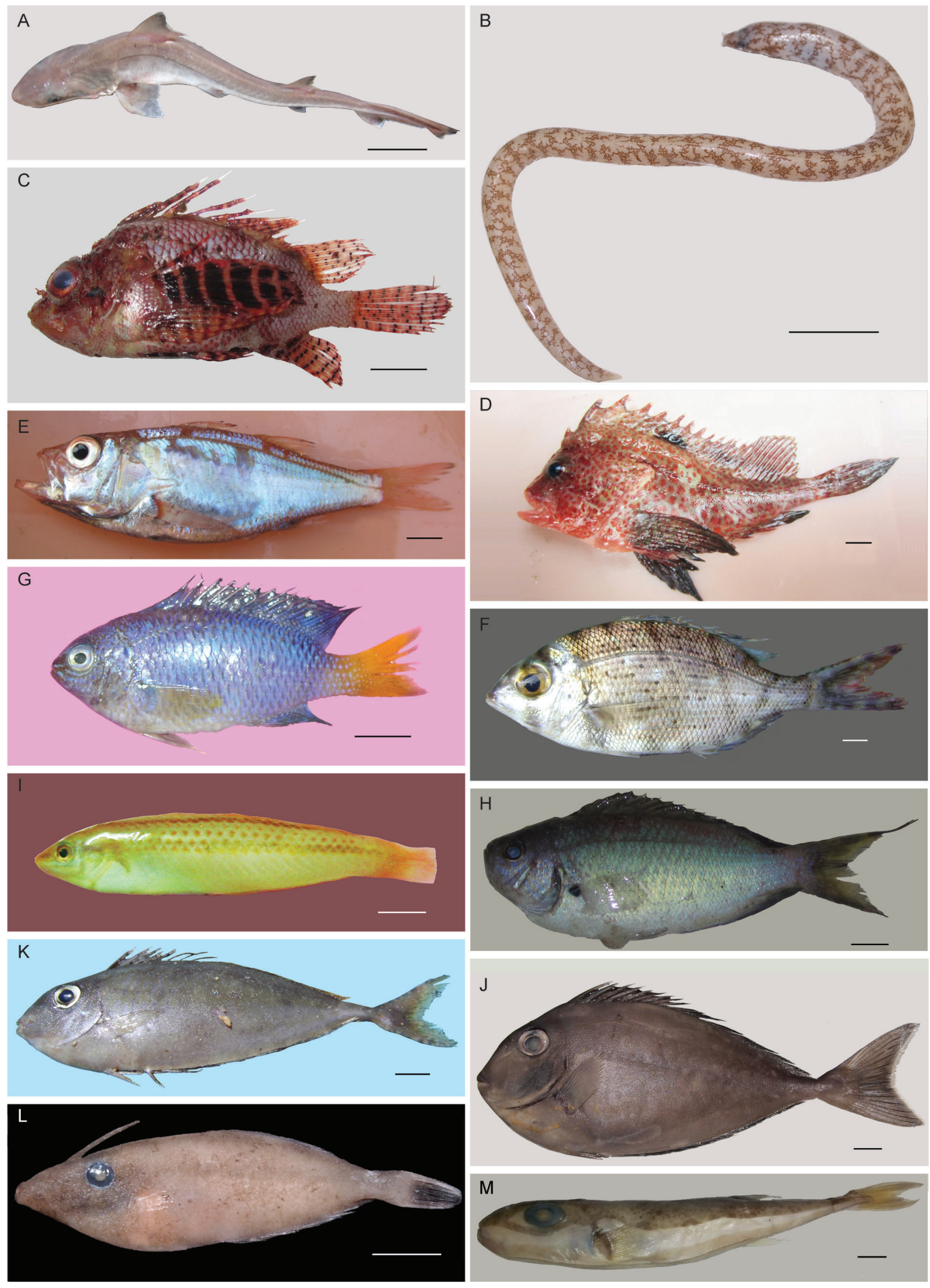

Fig. 2. Lateral views of newly recorded fishes from Gulf of Mannar: Hypogaleus hyugaensis (A), Uropterygius micropterus (B), Dendrochirus bellus (C), Snyderina guentheri (D), Acropoma japonicum (E), Gymnocranius elongatus (F), Pomacentrus similis $(\mathbf{G})$, Pristotis cyanostigma $(\mathbf{H})$, Leptojulis cyanopleura $(\mathbf{I})$, Naso annulatus $(\mathbf{J})$, Naso thynnoides (K), Pseudalutarius nasicornis (L), Lagocephalus suezensis (M); Scale bars: $5 \mathrm{~cm}(\mathrm{~A}) ; 1 \mathrm{~cm}$. (B-M) 
4B. Head not spiny, sub-orbital stay lacking; one or two dorsal fins, with IV-XIII spines; pectoral fin not reaching beyond anal fin origin; anal fin with II-III spines; caudal fin forked or rounded .6

5A. Lacrimal bone immobile, firmly attached to lateral ethmoid and first sub-orbital bones, with only short downward pointing spine; D fin commences posterior to eye, its height greater than $50 \%$ of $\mathrm{BD}$, membranes between spines deeply incised; lower 5-7 pectoral rays free from rest of the fin ................... Dendrochirus bellus 5B. Lacrimal bone mobile, hinged to lateral ethmoid and abutting first sub-orbital, with short downward pointing spine and long posterior spine reaching behind middle of eye; D fin commencing above middle of eye, its height lesser than $50 \%$ of $\mathrm{BD}$, membranes between spines partly incised; pectoral fin without free rays....Snyderina guentheri

6A. Pelvic rays 5 in number. ... 7

6B. Pelvic rays 3 in number.

7A. Two dorsal fins, first dorsal with VII spines, second dorsal with I spine and 9 soft rays...Acropoma japonicum 7B. Single dorsal fin with IX-XIII spines and 10-14 soft rays

8A. Lower pharyngeals not fused; gill rakers knob-like. Dorsal and anal fins with 10 soft rays each. Caudal fin strongly forked. Lower edge of eye intersected by line between snout tip and caudal fork...Gymnocranius elongatus

8B. Lower pharyngeal fused to form pharyngeal jaw plate; gill rakers simple. Dorsal soft rays 11-14, anal soft rays $11-14$

9A. Nostrils 2 pairs. Pre-orbital and sub-orbital bones attached to cheek. Anterior-most pair of upper jaw teeth caniniform and forward projecting. Scales cycloid. Dorsal fin with IX spines and 11 soft rays, anal spines III ....

Leptojulis cyanopleura

9B. Nostrils 1 pair. Pre-orbital and sub-orbital bones not attached to cheek. Jaw teeth conical to incisiform. Scales ctenoid. Dorsal fin with XIII spines and 13-14 soft rays, anal spines II

.. 10

10A. Jaw teeth uniserial. Scales in longitudinal series 32-34. Pale grey coloured, each dermal scale with a conspicuous blue spot ...................Pristotis cyanostigma 10B. Jaw teeth biserial. Scales in longitudinal series 2530. Bright blue coloured, dorsal, anal and pelvic fins blue, pectoral fin transparent yellow, caudal fin bright yellow. Pomacentrus similis

11A. Caudal peduncle with two plates on either side. Dorsal fin with V spines. Body depth $47.40 \%$ of SL. Caudal fin with white posterior margin....Naso annulatus
11B. Caudal peduncle with one plate on either side. Dorsal fin with IV spines. Body depth $30.80 \%$ of SL. Caudal fin grey Naso thynnoides

12A. Jaw teeth distinct, pointed. Dorsal fin well in advance of eye, with II spines (first long, second minute), 43 soft rays; anal fin with 41 soft rays...Pseudalutarius nasicornis

12B. Jaw teeth fused to form four dental plates with strong cutting edges. Dorsal fin posterior to mid-point of body, without spines, soft rays 10; anal fin with 9 soft rays. Prickly area on the back extends from behind the eye to dorsal fin origin. Body light greenish dorsally, covered with unequal sized dark spots ......Lagocephalus suezensis

\section{DISCUSSION}

The Gulf of Mannar, located off the south-eastern coast of India, is among the biologically richest marine ecosystems in the Indian Ocean region. The presence of myriad numbers of rare reef-associated as well as deep sea fishes suggests that structural complexities among the bottom habitats particularly coral reefs have facilitated the establishment of micro-niches that provide safe haven for diverse assemblages of demersal fishes. Moreover, the development of coastal demersal fisheries and expansion of fishing fleets has recently further enabled the discovery of many rare species (Padate et al. 2014). However, excessive mechanized fishing activity in this fragile biosphere reserve has adversely affected the unique coral reef and sea-grass ecosystems (Diraviya Raj et al. 2017). The presently reported sampling survey corroborated that large mechanized fishing vessels employ bottom trawls to harvest reef fishes and invertebrates in coastal shelf waters, and also use mid-water trawls in deeper offshore waters to harvest tuna and other pelagic fishes. Moreover, several rare reef-associated fishes caught incidentally by shrimp trawlers are regularly dumped at major fishing harbours along the Gulf of Mannar coast as evident from few specimens collected during this study.

In view of this, it was pertinent to document demersal fish fauna affected by mechanized fisheries of the region. This effort comprising only 23 bottom trawl hauls up to $153 \mathrm{~m}$ depth revealed seven elasmobranchs and 190 teleostean taxa. These observations confirm the removal of myriad varieties of demersal fishes at an alarming rate. The present observations revealed that among the thirteen new records, the triakid shark genus Hypogaleus and the monacanthid genus Pseudalutarius were recorded for the first time from the Indian region. These observations suggested that unabated alteration of their natural habitats might have reduced the habitat complexity of the fishing grounds thereby rendering these species vulnerable to fishing.

A review of the biogeographical aspects of the newly recorded species revealed that five out of thirteen species had restricted zoogeographical distributions. Dendrochirus bellus was previously known only from the western Pacific regions, Gymnocranius elongatus from the eastern Indian Ocean and western Pacific regions, Pomacentrus 
similis from the eastern Indian Ocean, and two species (Pristotis cyanostigma and Lagocephalus suezensis) from the Red Sea). The Red Sea region has high endemicity of marine fishes $(13.6 \%)$ attributed to its isolation from the Indian Ocean during glacial periods (Eschmeyer et al. 2010). The Indo-Australian archipelago, straddling the eastern Indian Ocean and western Pacific regions, is a complex geographical entity, whose high species diversity and endemicity are attributed to recurring vicariance (geographical separation of a population owing to physical barriers) events during the past 50 million years (Lohman et al. 2011). The present observations make it pertinent to suggest that the Gulf of Mannar region might have experienced vicariance events in the geological past that resulted in the isolation of reef fish populations from similar populations in the Indo-Australian archipelago (Sorenson et al. 2014). Moreover, rapid northward drift of the Indian subcontinent from Africa over the past 200 million years (Yoshida and Hamano 2015), coupled with isolation of the Red Sea during the glacial periods (Eschmeyer et al. 2010) might have contributed to the separation of their respective populations.

\section{ACKNOWLEDGEMENTS}

The authors take this opportunity to express their gratitude to the Ballast water Management Programme, India (BAMPI) executed by CSIR - National Institute of Oceanography, Goa for Directorate General of Shipping, Ministry of Shipping, Government of India. We are grateful to Dr. Hiroyuki Motomura, Professor, Kagoshima University Museum, Japan and Dr. Makoto Okamoto, Seikai National Fisheries Research Institute, Nagasaki, Japan for providing us valuable references. This is a joint contribution of the Goa University and National Institute of Oceanography (NIO contribution No. 6061).

\section{REFERENCES}

Allen G.R. 1991. Damselfishes of the world. Mergus Publishers, Melle, Germany.

Allen G.R. 2001. Pomacentridae: Damselfishes (anemonefishes). Pp. 3337-3356. In: Carpenter K.E., Niem V.H. (eds.) FAO species identification guide for fishery purposes. The living marine resources of the Western Central Pacific. Vol. 5. Bony fishes Part 3 (Menidae to Pomacentridae). FAO, Rome.

Anonymous 2010. Manappad to Setukkarai; Indian Nautical Chart No. 224. National Hydrographic Office, Dehradun, India.

Bleeker P. 1865. Énumération des espèces de poissons actuellement connues de l'île de Céram. Nederlandsch Tijdschrift voor de Dierkunde 2: 182-193.

Böhlke E.B., McCosker J.E. 2001. The moray eels of Australia and New Zealand, with the description of two new species (Anguilliformes: Muraenidae). Records of the Australian Museum 53 (1): 71-102. DOI: $10.3853 /$ j.0067-1975.53.2001.1325

Böhlke E.B., McCosker J.E., Smith D.G. 1999. Muraenidae: Morays. Pp. 1643-1657. In: Carpenter K.E., Niem V.H. (eds.) FAO species identification guide for fishery purposes. The living marine resources of the Western Central Pacific. Vol. 3. Batoid fishes, Chimaeras and bony Fishes Part 1 (Elopidae to Linophrynidae). FAO, Rome.

Borsa P., Béarez P., Chen W.-J. 2010. Gymnocranius oblongus, a new large-eye bream species from New Caledonia (Teleostei: Lethrinidae). Comptes Rendus Biologies 333 (3): 241-247.

DOI: $10.1016 /$ j.crvi.2009.12.015

Borsa P., Béarez P., Paijo S., Chen W.-J. 2013. Gymnocranius superciliosus and Gymnocranius satoi, two new large-eye breams (Sparoidea: Lethrinidae) from the Coral Sea and adjacent regions. Comptes Rendus Biologies 336 (4): 233-240.

DOI: $10.1016 /$ j.crvi.2013.06.003

Carpenter K.E., Allen G.R. 1989. FAO species catalogue. Emperor fishes and large-eye breams of the world (family Lethrinidae). An annotated and illustrated catalogue of lethrinid species known to date. Pp. 1-118. FAO Fisheries Synopsis No. 125, Vol. 9. FAO, Rome.

Compagno L.J.V., Niem V.H. 1998. Triakidae: Houndsharks, smoothhounds, topes. Pp. 1297-1304. In: Carpenter K.E., Niem V.H. (eds.) FAO species identification guide for fishery purposes. The living marine resources of the Western Central Pacific. Vol. 2. Cephalopods, crustaceans, holothurians and sharks. FAO, Rome.

Cubelio S.S., Remya R., Madhusoodana Kurup B. 2011. A new species of Mustelus (Family: Triakidae) from Indian EEZ. Indian Journal of Geo-marine Sciences $\mathbf{4 0}$ (1): 28-31.

Devi K., Sadhukhan K., Yogesh Kumar J.S., Kumar Shah S. 2015. [Chapter 14] New record of reef fishes from the Andaman and Nicobar Islands. Pp. 225-234. DOI: $\quad$ 10.1016/B978-0-12-801948-1.00014-8 In: Venkataraman K., Sivaperuman C. (eds.) Marine faunal diversity in India: Taxonomy, ecology and conservation. Academic Press, USA. DOI: 10.1016/B978-0-12-801948-1.00030-6

Diraviya Raj K., Monolisha S., Patterson Edward J.K. 2017. Impacts of traditional shore seine operation along the Tuticorin coast, Gulf of Mannar, southeast India. Current Science 112 (1): 40-45. DOI: $10.18520 / \mathrm{cs} / \mathrm{v} 112 / \mathrm{i} 01 / 40-45$

Eschmeyer W.N., Fricke R., Fong J.D., Polack D.A. 2010. Marine fish diversity: History of knowledge and discovery (Pisces). Zootaxa 2525: 19-50.

Farrag M.M.S., El-Haweet A.A.K., El-Sayed kh A.A., Moustafa M.A. 2016. Occurrence of puffer fishes (Tetraodontidae) in the eastern Mediterranean, Egyptian coast-filling in the gap. BioInvasions Records 5 (1): 47-54.

DOI: $10.3391 /$ bir.2016.5.1.09

Fischer W., Bianchi G. 1984. FAO species identification sheets for fishery purposes. Western Indian Ocean (Fishing Area 51). Vols. 1-6. FAO Rome.

Froese R., Pauly D. (eds.) 2016. Fishbase. [version 06/2016]. http://www.fishbase.org 
Ho H.-C., Shen K.-N., Chang C.-W. 2011. A new species of the unicornfish genus Naso (Teleostei: Acanthuridae) from Taiwan, with comments on its phylogenetic relationship. The Raffles Bulletin of Zoology 59 (2): 205-211.

Hutchins J.B. 2001. Monacanthidae. Filefishes (Leatherjackets). Pp. 3929-3947. In: Carpenter K.E., Niem V.H. (eds.) FAO species identification guide for fishery purposes. The living marine resources of the Western Central Pacific. Vol. 6. Bony Fishes Part 4 (Labridae to Latimeriidae), estuarine crocodiles, sea turtles, sea snakes and marine mammals. FAO, Rome.

Iwatsubo H., Ito M., Nakao K., Meguro M., Matsunuma M., Motomura H. 2009. [Records of Lagocephalus suezensis (Tetraodontiformes: Tetraodontidae) from southern Kyushu, Japan.] Bulletin of the Biogeographical Society of Japan 64: 21-27. [In Japanese.]

Johnson J.W. 2002. Naso mcdadei, a new species of unicornfish (Perciformes: Acanthuridae), with a review of the Naso tuberosus species complex. Australian Journal of Zoology 50 (3): 293-311.

DOI: $\underline{10.1071 / \mathrm{ZO} 01049}$

Kathal P.K. 2005. Sethusamudram Ship Canal Project: Oceanographic/geological and ecological impact on marine life in the Gulf of Mannar and Palk Bay, southeastern coast of India. Current Science 89 (7): 1082-1083.

Kim M.J., Hwang U.W., Song C.B. 2010. First record of Snyderina yamanokami (Pisces: Scorpaeniformes) from Korea. Fisheries and Aquatic Sciences 13 (3): 257-259.

DOI: $10.5657 /$ fas.2010.13.3.257

Liu S.-Y.V., Ho H.-C.H., Dai C.-F. 2013. A new species of Pomacentrus (Actinopterygii: Pomacentridae) from Micronesia, with comments on its phylogenetic relationships. Zoological Studies 52: 6-13.

DOI: $\underline{10.1186 / 1810-522 X-52-6}$

Loh K.-H., Chen I.-S., Randall J.E., Chen H.-M. 2008. A review and molecular phylogeny of the moray eel subfamily Uropterygiinae (Anguilliformes: Muraenidae) from Taiwan, with description of a new species. The Raffles Bulletin of Zoology Supplement 19: $135-150$.

Lohman D.J., de Bruyn M., Page T., von Rintelen K., Hall R., Ng P.K.L., Shih H.-T., Carvalho G.R., von Rintelen T. 2011. Biogeography of the IndoAustralian Archipelago. The Annual Review of Ecology, Evolution, and Systematics 42: 205-226. DOI: 10.1146/annurev-ecolsys-102710-145001

Matsunuma M., Motomura H. 2013. A New lionfish of the genus Dendrochirus (Scorpaenidae: Pteroinae) from the Tuamotu Archipelago, South Pacific Ocean. Species Diversity 18 (1): 1-7.

DOI: $10.12782 / \mathrm{sd} .18 .1 .001$

Matsuura K. 2001. Tetraodontidae: Puffers. Pp. 39543957. In: Carpenter K.E., Niem V.H. (eds.) FAO species identification guide for fishery purposes. The living marine resources of the Western Central Pacific. Vol.
6. Bony Fishes Part 4 (Labridae to Latimeriidae), estuarine crocodiles, sea turtles, sea snakes and marine mammals. FAO, Rome.

Matsuura K. 2015. Taxonomy and systematics of tetraodontiform fishes: A review focusing primarily on progress in the period from 1980 to 2014. Ichthyological Research 62 (1): 72-113.

DOI: $\underline{10.1007 / \mathrm{s} 10228-014-0444-5}$

McCosker J.E., Smith D.G. 1997. Two new Indo-Pacific morays of the genus Uropterygius (Anguilliformes: Muraenidae). Bulletin of Marine Science 60 (3): 1005-1014.

Okamoto M.2014. Acropoma profundum, a new species of lanternbelly (Teleostei: Perciformes: Acropomatidae) from the Solomon Islands. Species Diversity 19 (1): 9-14.

DOI: $\underline{10.12782 / \mathrm{sd} .19 .1 .009}$

Padate V.P., Rodrigues R., Rivonker C.U. 2014. New records of rare marine fishes from the Gulf of Mannar, India. Acta Ichthyologica et Piscatoria 44 (3): 241248.

DOI: $10.3750 / A I P 2014.44 .3 .08$

Poss G.S. 1999. Scorpaenidae: Scorpionfishes (also, lionfishes, rockfishes, stingfishes, stonefishes and waspfishes). Pp. 2291-2352. In: Carpenter K.E., Niem V.H. (eds.) FAO species identification guide for fishery purposes. The living marine resources of the Western Central Pacific. Vol. 4. Bony Fishes Part 2 (Mugilidae to Carangidae). FAO, Rome.

Prakash S., Kumar T.T.A. 2016. A first record of the lined wrasse Anampses lineatus Randall, 1972 (Perciformes: Labridae) in the Gulf of Mannar, Tamil Nadu, India. Journal of Threatened Taxa 8 (6): 8923-8926.

DOI: $10.11609 /$ jott.1984.8.6.8923-8926

Psomadakis P.N., Osmany H.B., Moazzam M. 2015. Field identification guide to the living marine resources of Pakistan. FAO Species Identification Guide for Fishery Purposes. FAO, Rome.

Randall J.E. 1994. Unicornfishes of the subgenus Axinurus (Perciformes: Acanthuridae: Naso), with description of a new species. Copeia 1994 (1): 116-124. DOI: $\underline{10.2307 / 1446677}$

Randall J.E. 1996. Second revision of the labrid fish genus Leptojulis, with descriptions of two new species. Indo-Pacific Fishes No. 24, Bernice Pauahi Bishop Museum, Honolulu, Hi, USA.

Randall J.E. 2001a. Acanthuridae: Surgeonfishes (tangs, unicornfishes). Pp. 3653-3683. In: Carpenter K.E., Niem V.H. (eds.) FAO species identification guide for fishery purposes. The living marine resources of the Western Central Pacific. Vol. 6. Bony Fishes Part 4 (Labridae to Latimeriidae), estuarine crocodiles, sea turtles, sea snakes and marine mammals. FAO, Rome.

Randall J.E. 2001b. Naso reticulatus, a new unicornfish (Perciformes: Acanthuridae) from Taiwan and Indonesia, with a key to the species of Naso. Zoological Studies 40 (2): 170-176.

Rao D.V., Devi K., Rajan P.T. 2000. An account of ichthyofauna of Andaman and Nicobar Islands, Bay 
of Bengal. Records of the Zoological Survey of India, Occasional paper No. 178.

Robertson D.R., Grove J.S., McCosker J.E. 2004. Tropical transpacific shore fishes. Pacific Science $\mathbf{5 8}$ (4): 507-565. DOI: $10.1353 /$ psc. 2004.0041

Rüppell W.P.E.S. 1838. Fische des rothen Meeres. [Fische aus dem rothen Meere.] 148 pages and 33 figure plates. In: Rüppell W.P.E.S. Neue Wirbelthiere zu der Fauna von Abyssinien gehörig. Siegmund Schmerber, Frankfurt am Main.

DOI: $\underline{10.5962 / \text { bhl.title. } 53778}$

Senta T. 1973. A new sparoid fish, Gymnocranius elongatus from the southern South China Sea. Japanese Journal of Ichthyology 20 (3): 135-144.

DOI: $10.11369 / \mathrm{jji} 1950.20 .135$

Sluka R.D. 2013. Coastal marine biodiversity along the western coast of India. Journal of Threatened Taxa 5 (1): $3574-3579$.

DOI: $10.11609 / J_{0 T T} .03187 .118$

Smith D.G. 2012. A checklist of the moray eels of the world (Teleostei: Anguilliformes: Muraenidae). Zootaxa 3474: 1-64.

Smith J.L.B. 1957. A new shark from Zanzibar, with notes on Galeorhinus Blainville. Annals and Magazine of Natural History (Series 12) 10 (116): 585-592.

DOI: $\underline{10.1080 / 00222935708656002}$

Smith M.M., Heemstra P.C. 1986. Smith's Sea Fishes. Springer-Verlag, Berlin, Heidelberg, New York, London, Paris, Tokyo.

Sorenson L., Allen G.R., Erdmann M.V., Dai C.-F., Liu S.-Y.V. 2014. Pleistocene diversification of the Pomacentrus coelestis species complex (Pisces: Pomacentridae): historical biogeography and species boundaries. Marine Biology 161 (11): 2495-2507. DOI: $10.1007 / \mathrm{s} 00227-014-2521-8$

Talwar P.K. 1977. The rare deep-water scorpion-fish Snyderina guentheri in Indian Seas. Copeia 1977 (3): 580-581.
DOI: $10.2307 / 1443284$

Thomas P.A. 1970. On some deep sea sponges from the Gulf of Mannar, with descriptions of three new species. Journal of the Marine Biological Association of India 12 (1-2): 202-209.

Tyler J.C. 1966. A new species of damselfish (Pomacentridae) from the western Indian Ocean, Pristotis judithae. Notulae Naturae of the Academy of Natural Sciences of Philadelphia No. 393: 1-6.

Venkataraman K., Jeyabaskaran R., Satyanarayana C., Raghuram K.P. 2004. Status of coral reefs in Gulf of Mannar Biosphere Reserve. Records of the Zoological Survey of India 103 (1-2): 1-15.

Westneat M.W. 2001. Labridae: Wrasses (also, hogfishes, razorfishes, corises, and tuskfishes). Pp. 3381-3467. In: Carpenter K.E., Niem V.H. (eds.) FAO species identification guide for fishery purposes. The living marine resources of the Western Central Pacific. Vol. 6. Bony Fishes Part 4 (Labridae to Latimeriidae), estuarine crocodiles, sea turtles, sea snakes and marine mammals. FAO, Rome.

Yogesh Kumar J.S., Geetha S., Sornaraj R. 2013. [Chapter 19] Diversity and distribution of reef fishes in Gulf of Mannar Islands, India. Pp. 297-310. DOI: $\quad 10.1007 / 978-3-642-38200-0 \quad 19$ In: Venkataraman K., Sivaperuman C., Raghunathan C. (eds.) Ecology and conservation of tropical marine faunal communities. Springer, Heidelberg, New York, Dordrecht, Berlin.

DOI: $10.1007 / 978-3-642-38200-0$

Yoshida M., Hamano Y. 2015. Pangea breakup and northward drift of the Indian subcontinent reproduced by a numerical model of mantle convection. Scientific Reports 5 (8407): 1-7.

DOI: $10.1038 /$ srep08407

Received: 27 October 2016

Accepted: 24 March 2017

Published electronically: 30 June 2017 